\title{
POTENTIAL ROLE OF GLP-1 RECEPTOR AGONIST IN A RAT MODEL OF CARDIO-RENAL SYNDROME TYPE-3: EFFECTS ON OXIDATIVE, INFLAMMATORY AND INOS EXPRESSION AXIS
}

\author{
Atef M. Abood ${ }^{1,2}$, Hosam Ahmed Awad ${ }^{1,2}$, and Sherif M Hassan ${ }^{3,4}$
}

\begin{abstract}
${ }^{1}$ Physiology Department, Faculty of Medicine, Kingabdulaziz University, Jeddah, Saudi Arabia ${ }^{1}$ and Faculty of Medicine, Ain Shams University, Cairo, Egypt ${ }^{2}$ Anatomy and histology department, Faculty of medicine, Kingabdulaziz University, Jeddah, Saudi ${ }^{3}$ Arabia and ${ }^{3}$ Anatomy department, Faculty of Medicine, Al-Azhar University, Cairo, Egypt. ${ }^{4}$

Corresponding author

Atef M. Abood ${ }^{1,2}$

Mobile: 01098085038,

E.mail: rowaanagy@gmail.com.

Received: $12 / 10 / 2020$

Accepted: 10/11/2020
\end{abstract}

Online ISSN: 2735-3540

\section{ABSTRACT}

Background: Acute renal and cardiac diseases are common encounters in hospitalized and non-hospitalized patients. Kidney and heart pathology are continuously interrelated. The impact of acute kidney injury (AKI) on the cardiac function is demonstrated in both preclinical and clinical studies and is termed cardio-renal syndrome type 3.

Aim of the work: The aim of this work is to establish an animal model of cardio-renal syndrome type 3, and to study the effect of glucagon-like peptide-1 receptor (GLP-1R) agonist "liraglutide" on this condition.

Materials and methods: Sixty male Wistar rats were used in this study and were divided into six groups (10 per group). Group 1: control, Group 2: low dose liraglutide-treated rats(L-lira). Group 3: high dose liraglutide-treated rats (H-lira). Group 4: Gentamicin (GM) treated rats. Group 5: low dose liraglutide- and GM-treated rats ( $L$ lira-GM). Group 6: high dose liraglutide- and GM-treated rats ( $\mathrm{H}$ lira-GM). Liraglutide was given daily by subcutaneous injection for three weeks. GM was injected intraperitoneally (IP) starting from day 15 to day 21.

Results: GM treatment was associated with histopathological injuries of both renal and cardiac tissues, in addition to significant elevation of renal biomarkers (serum urea and creatinine) as well as cardiac biomarkers (cardiac troponin I (TnI), creatine kinase (CK$M B)$ and lactate dehydrogenase (LDH). ECG showed prolongation of $Q R S$ complex, $Q-T$ and $Q-T c$ interval, in addition to increased $T$ wave voltage. There was significant increase in the relative weight of the right ventricle and the absolute and relative weights of left ventricles and the whole heart of the GM group. Moreover, GM injection resulted in a significant increase in oxidative and inflammatory markers (MDA, NO, IL-1beta, IL-6 and TNF- $\alpha$ ) and diminished antioxidants GSH, SOD, and catalase, in the serum as well as in renal and cardiac tissues. GLP-1R agonist administration before GM injection normalized all the measured parameters only in the high dose group. Liraglutide evidently prevented upregulation of the inducible nitric oxide synthase (iNOS) gene expression in both renal and cardiac tissue of GM-treated animals.

Conclusion: GM injected rats exhibited renal and cardiac structural and functional damage. The GLP-1R agonist, liraglutide protects both the kidney and the heart through antioxidant and antiinflammatory effects. In addition, it downregulates the iNOS expression in renal and cardiac tissues, thus decreasing production of nitric oxide (NO). 
Keywords: GLP-1 receptor agonist - liraglutide - cardiorenal syndrome - iNOS - capsase-1

\section{INTRODUCTION:}

Cardiac and renal disturbances are common encounters in both inpatient and outpatient clinics. There is a complex interaction between renal and cardiac dysfunctions, where pathology in one organ affects the other ${ }^{(1)}$. The term cardio-renal syndrome emerges in the literature to describe this mutual cross talk between the two vital organs. Cardio-renal syndrome is divided into five subtypes according to the onset and the sequence of the lesion. Cardiorenal syndrome type 3 is a subtype of this syndrome, although the name is misleading. In this subtype, AKI results in acute cardiac insult ${ }^{(2)}$.

Cardiac failure is the most common cause of death in patients with AKI who proceed to cardiac disorders, ${ }^{(3)}$. Nikolic et al reported that cardiac dysfunction related to AKI may involve decompensated heart failure, ischemic heart disease and cardiac arrythmias. The renal contribution to cardiac pathology might be related to the direct cardio-renal connectors. These connectors include; inflammatory mediators, oxidative stress, cellular apoptosis and activation of both sympathetic nervous system and reninangiotensin aldosterone system. The indirect effects include; volume overload, metabolic acidosis and uremic toxins ${ }^{(4)}$.

Inflammation likely plays a key role in the crosstalk between the kidneys and the heart. In animal models of renal ischemic injury, cellular injury triggers nonspecific adaptive immunity pathways with consequent activation and recruitment of inflammatory cells into the kidneys ${ }^{(5)}$.

The activation of immune cells leads to secretion of chemokines and proinflammatory cytokines into the circulation, with potential widespread effects. Increased serum levels of interferon gamma (IFN- $\gamma$ ), tumor necrosis factor $-\alpha$ (TNF- $\alpha)$, interleukin 1b (IL1b), IL6, and IL18 have been observed in animal models of $\mathrm{AKI}^{(6)}$.

Increased oxidative stress, and diminished antioxidant defense in patients with kidney failure lead to increased risk for cardiac events ${ }^{(7)}$. The role of excessive production of $\mathrm{NO}$ and the associated upregulation of inducible nitric oxide synthase (iNOS) gene have, also, been implicated in the pathogenesis of acute kidney and cardiac injuries ${ }^{(8,9)}$.

Glucagon-like peptide-1 (GLP-1), a 30amino-acid hormone produced in the intestinal epithelial endocrine $L$ cells by differential processing of proglucagon, is a well-known insulinotropic hormone ${ }^{(10)}$. GLP-1 receptor agonists exert the same biological actions of GLP-1, including the glucose-dependent stimulation of insulin secretion, and inhibition of glucagon release $^{(11)}$. These agonists are currently being used for glycemic control in diabetic patients $^{(12)}$. The expression of GLP-1 receptors is not limited to the pancreas and is present in other non-digestive organs including the kidney, the heart and the blood vessels $^{(13,14)}$.

In fact, GLP-1R agonists have direct beneficial effects on the heart such as improving left ventricular performance after myocardial infarction ${ }^{(15)}$. They, also, protect against cardiac ischemia ${ }^{(16)}$ and the progression of atherosclerosis ${ }^{(17)}$.

On the other hand, the effects of GLP$1 \mathrm{R}$ agonists, liraglutide and exenatide in the setting of AKI are controversial. While Kodera et al. ${ }^{(18)}$ reported a protective role of GLP-1R agonist in renal injuries, LópezRuiz et al. reported acute renal failure when exenatide is co-administered with diuretics and angiotensin II blockers ${ }^{(19)}$. 


\section{AIM OF THE WORK:}

The aim of this study is multifaceted. First aim is to establish a successful animal model of cardio-renal syndrome type 3 . Second, is to test the potential effects of GLP-1R agonist liraglutide in this animal model. Lastly, to explain the mechanisms underlying these effects.

\section{MATERIALS AND METHODS:}

\section{Animals:}

This study was conducted in the King Fahd Center for Medical Research, KAU, Jeddah, Saudi Arabia from August to October 2020. The study involved 60 male Wistar rats, 5-6 months old (200-250g in weight). Animals were kept under standard conditions of boarding. The rats were allowed free access to water and ad libitum feeding. The study conforms to the NIH guidelines for the care of laboratory animals.

\section{Experimental design (table:1):}

Animals were initially weighed and divided into 6 groups, 10 rats in each group.

Group I: Control group: treated with vehicle only (distilled water) for three weeks.

Table 1: experimental protocol:
Group II: Low dose liraglutide-treatedrats (L-lira): Liraglutide was injected SC in a dose of 50 micrograms per $\mathrm{kg}$ of body weight for 3 weeks.

Group III: High dose liraglutide-treated group (H-lira): Liraglutide was injected SC in a dose of 150 micrograms per $\mathrm{kg}$ of body weight for 3 weeks.

Group IV: GM-treated group (GM): the animals in this group were treated as control group until day 14. From day 15 to day 21, the animals were subjected to induction of AKI by intraperitoneal (IP) injection of GM sulphate (Memphis Company for Pharmacy and Chemical Ind., Cairo, Egypt) in a dose of $100 \mathrm{mg} / \mathrm{kg} /$ day $^{(20)}$.

Group V: Liraglutide low dose and GMtreated group (L-lira-GM): the animals of this group were treated with liraglutide in a similar way to L-lira group, thereafter, the animals received GM injection from day 15 to day 21 similar to the GM-treated group.

Group VI: Liraglutide high dose and GM-treated group (H-lira-GM): the animals of this group were treated with liraglutide in a similar way to $\mathbf{H}$ lira group, thereafter, the animals received GM injection from day 15 to day 21 similar to the GM-treated group. The doses of liraglutide were chosen according to previous investigators ${ }^{(21,22)}$.

\begin{tabular}{|l|l|l|}
\hline Group & Day 1-14 & Day 15-21 \\
\hline 1.Control & Vehicle injection (distilled water) & \\
\hline 2. L-lira & \multicolumn{2}{|l|}{ Liraglutide injection in a low dose and vehicle from day 15 to 21 } \\
\hline 3. H-lira & Liraglutide injection in a high dose and vehicle from day 15 to 21 \\
\hline 4. GM & Vehicle treatment (distilled water) & GM injection + vehicle \\
\hline 5. (L-lira-GM ) & Liraglutide injection in a low dose & liraglutide (low dose) \& GM injection \\
\hline 6. (H-lira-GM ) & Liraglutide injection in a high dose & liraglutide (high dose) \& GM injection \\
\hline
\end{tabular}

NB: The number of rats per group was changed due to death of 2 rats from the GM-treated group and one rat died from each of the H-lira, GM-L-lira and the GM-H-lira groups. The number of rats became as follows: each of control and L-lira groups $(n=10)$; $\mathrm{GM}(\mathrm{n}=8)$ and each of H-lira, GM-L-lira, and GM-H-lira ( $\mathrm{n}=9)$.

\section{Procedures:}

On day 22, twenty-four hours post last injection of GM, overnight fasting rats were subjected to the following experimental procedures: animals were weighed and anesthetized with thiopental sodium (Sandoz $\mathrm{GmbH}$, Kundl, Austria) in a dose of 40 $\mathrm{mg} / \mathrm{kg}$ IP and then subjected to the following procedures: 


\section{ECG recording:}

Anesthetized rats were placed in the supine position on a board and ECG was recorded continuously with standard artifactfree lead II (right forelimb to left hind limb). Needle electrodes were inserted SC into the paw pads of each rat, and connected to Biocare ECG 101 (Shenzhen Biocare Electronics Co., Ltd., China). The ECG was measured to determine duration of QRS complex, $\mathrm{R}-\mathrm{R}$ interval, $\mathrm{R}$ voltage, $\mathrm{T}$ voltage $\mathrm{Q}-\mathrm{T}$ and Q-Tc intervals. Q-Tc is the Q-T interval corrected to the heart rate according to Bazett formula.

\section{Tail cuff systolic blood pressure and heart rate measurements:}

Both heart rate and systolic blood pressure (SBP) were measured by tail-cuff plethy-smography (BP98A, Softron, Tokyo, Japan). The animals were kept at $25^{\circ} \mathrm{C}$ for 5 minutes, the first five cycles were considered as adaptation cycles. After that, five consecutive cycles were recorded and the average was calculated, as the mean systolic blood pressure.

Animals were, then, sacrificed and a mid-line abdominal incision was performed for the collection of whole blood specimen from the abdominal aorta. Blood was centrifuged at $3000 \mathrm{rpm}$ for 30 minutes. Serum was collected and stored at $-20^{\circ} \mathrm{C}$ for use in measurement of biochemical parameters.

The kidneys were carefully dissected, divided into two halves, one half was preserved in $10 \%$ formalin for histological examination, and the other half for biochemical measurements. Similarly, the heart was removed, blotted and weighed. Weights were determined as total heart weight and ventricular weights. All cardiac weights were expressed as absolute weight and as a ratio to the whole-body weight. Hearts were, then, preserved for biochemical measurements and real time PCR.
Tissue homogenates were prepared using Polytron PT1200E Disperser (Kinematica AG, Luzern, Switzerland) in ice-cold phosphate-buffered saline (PBS, $\mathrm{pH}$ 7.2). Homogenates were centrifuged at $12,000 \mathrm{rpm}$ for $10 \mathrm{~min}$, and supernatants were used for measurements.

\section{Biochemical assays:}

\section{Biomarkers for renal and cardiac functions:}

Serum glucose, creatinine, and urea were measured by colorimetric method using kits supplied by Diamond Diagnostic (Cairo, Egypt) according to manufacturer instructions. Serum cardiac troponin I (TnI) and the isoenzyme creatine kinase (CK-MB) were measured by ELISA kits supplied by Shanghai Crystal Day Biotech Co. (Shanghai, China) and Kamiya Biomedical Company (Seattle, WA, USA), respectively, according to the manufacturer instructions. Serum lactate dehydrogenase (LDH) activity was measured using a diagnostic kit supplied by Spinreact (Girona, Spain) according to the manufacturer instructions and as described previously by ${ }^{(23)}$.

\section{Oxidative and antioxidative markers:}

Malondialdehyde (MDA), nitric oxide (NO), reduced glutathione (GSH), superoxide dismutase (SOD) and catalase activities were measured in the serum, as well as in kidney and heart tissue homogenates. Lipid peroxidation was assessed by measuring the content of MDA, a byproduct of lipid peroxidation process. The measurement was performed using kits supplied by Diamond Diagnostics (Cairo, Egypt), according to the manufacturer instructions. This assay depends on the reaction of MDA in samples with thiobarbituric acid (TBA) forming a red MDA-TBA complex. The complex was assessed colorimetrically at wavelength 532 $\mathrm{nm}$. For determination of serum nitrates, as a stable end product of $\mathrm{NO}$, the end-point enzymatic one-step assay was carried out on 
the basis of the reduction of nitrate by nitrate reductase $^{(24)}$. GSH was assessed colorimetrically at wavelength $405 \mathrm{~nm}$ by using kits supplied by Bio Diagnostic (Giza, Egypt), according to the manufacturer instructions.

SOD and catalase activity were assessed in the serum colorimetrically using kits supplied by Bio Diagnostic (Giza, Egypt), according to the manufacturer instructions.

\section{Inflammatory markers:}

Levels of the pro-inflammatory cytokines: tumor necrosis factor- $\alpha$ (TNF- $\alpha)$, IL-1 $\boldsymbol{\beta}$, and IL-6 were measured in the serum and in both kidney and heart tissue homogenates according to the ELISA kit instructions (R\&D Systems, Inc., Minneapolis, MN, USA).

Measurement of gene expression of iNOs in kidney and heart tissue homogenates

RT-PCR for identification of iNOS-mRNA in both kidney and cardiac tissues

Total RNA was extracted using TRIzol Reagent (Invitrogen, Life Technologies, USA) according to the manufacturer's instructions. Reverse transcription was Table 2: primers used for Real time-PCR carried out with the High Capacity cDNA Reverse Transcription Kit (Applied Biosystems). PCR was performed with Taq DNA polymerase. The primers used for assessment of iNOS and the GADPH gene, as a control, are shown in table1.

The thermal cycle was set as follows: inactivation of reverse transcriptase at $95^{\circ} \mathrm{C}$ for 10 minutes, followed by 45 cycles of $95^{\circ} \mathrm{C}$ for 30 seconds, $60^{\circ} \mathrm{C}$ for 1 minute, and $72^{\circ} \mathrm{C}$ for 30 seconds. Dissociation curve analysis was used for confirmation of PCR results. Using ABI's SDS software, the data were depicted as sigmoid shaped amplification plots in which the number of cycles was plotted against fluorescence on a linear scale. The threshold cycle serves as a tool for calculation of the starting template amount in each sample. Because the samples of the control group and also samples of the treated group were used as calibrators, the expression levels were set to1.The relative concentration of the genes were normalized against the glyceraldehyde-3-phosphate dehydrogenase GADPH and gene expression fold changes were calculated using the equation $2-\Delta \Delta \mathrm{ct}^{(25)}$.

\begin{tabular}{|l|l|}
\hline iNOS & $\begin{array}{l}5^{*} \text {-AGCACATGCAGAAATGAGTACCG-3* } \\
5^{*} \text {-CCGTCAGAGGTAACTGTTTACACG3*, }\end{array}$ \\
\hline GADPH & $\begin{array}{l}5^{\prime} \text {-GACATGCCGCCTGGA GAAAC-3' } \\
5^{\prime} \text {-AGCCCAGGATGCCCTT TAGT-3' }\end{array}$ \\
\hline
\end{tabular}

\section{Histopathological studies:}

Specimens of the kidney and the heart from different groups were fixed in $10 \%$ phosphate-buffered formalin solution at room temperature. Specimens were dehydrated in graded ethanol $(70-100 \%)$, cleared in xylene and embedded in paraffin. Paraffin-embedded tissue sections $(5 \mathrm{~mm}$ thick) were prepared, mounted on slides and kept at room temperature. Thereafter, slides were dewaxed in xylene; hydrated using graded ethanol and stained by hematoxylin and eosin (HE) dyes. The sections were examined under light microscope and photographed ${ }^{(26)}$.

\section{Statistical analysis:}

Data were expressed as mean \pm SEM. The Student's t-test for and unpaired data was performed to assess them as statistically significant intragroup and intergroup differences, respectively. All statistical data and statistical significance were analyzed using the Statistical Package for Social Sciences (SPSS Inc., Chicago, Illinois, 
USA), version 16. A P value less than 0.05 was considered statistically significant.

\section{RESULTS}

Treatment of normal rats with low dose (Group 2) or high dose liraglutide (Group 3) did not show any significant changes in all investigated parameters when these rats were compared with their matching controls. The results are shown in all figures and tables alongside with the results of other groups.

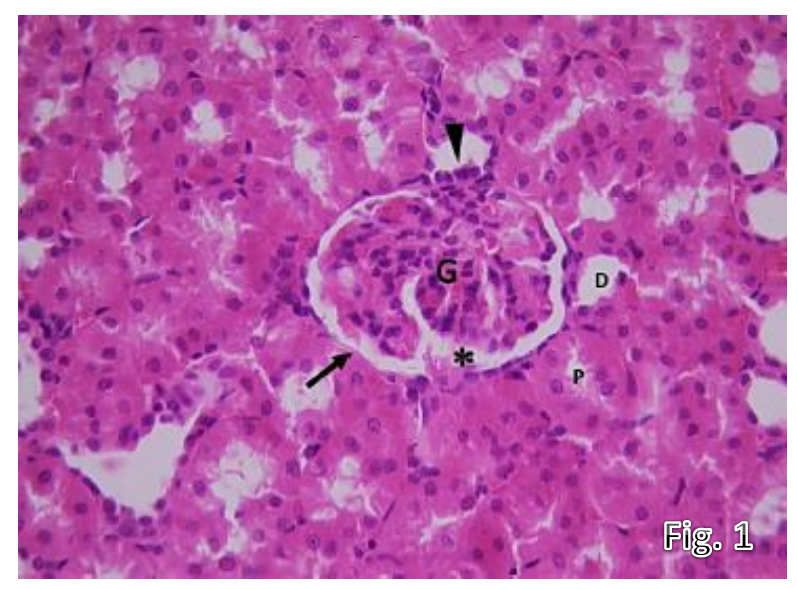

Figure 1: Sections from cortex of kidney of normal rats (control group) showing normal histological feature. spherical renal corpuscle enclosed in the Bowman's capsule $(\uparrow)$. The figure, also, shows the normal spherical glomerulus $(G)$ with the Bawman's space around it, normal proximal convoluted tubule $(\mathrm{P})$, distal convoluted tubule (D) and macula densa $(\boldsymbol{\Delta})$. (H\&E X400)

The histological features of the renal cortex from L-lira and H-lita treated animals (Groups 2 and 3) showed a histological profile comparable to the control group. (Figure 2).

On the contrary, renal cortex of kidneys from GM -treated group (Group 4) showed marked damage. Renal tubules were not clearly identified. The lumina of the tubules showed vacuolation and were obliterated by

\section{Hematoxylin and Eosin stained sections of the renal cortex of the studied groups:}

Renal cortical sections from normal control animals (Group 1) stained with $\mathrm{H} \& \mathrm{E}$ had completely normal features. They showed normal spherical glomerular corpuscles with intact Bowman's capsule and narrow Bowman's space. Normal glomeruli, normal proximal and distal convoluted tubules with normal cell lining were seen (Figure 1).

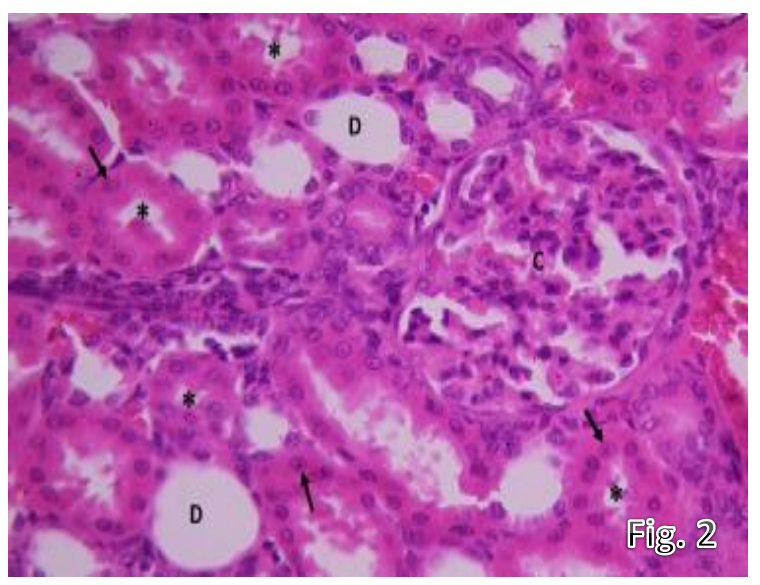

Figure 2 The histological features of renal cortex from high dose liraglutide-treated animals (H-lira). showed a histological profile comparable to the control group. Normal intact renal glomeruli, and Bowman's capsule as well as proximal and distal convoluted tubules. (H\&E X400)

the sloughed cells. Furthermore, homogenyous eosinophilia were found in the tubular lumina in some tubules. The epithelium lining of some tubules showed pyknosis. Inflammatory cells and congested peritubular capillaries were found in between the tubules of the renal cortex. In addition, glomerular capillaries appeared shrunken (Figures 3). 


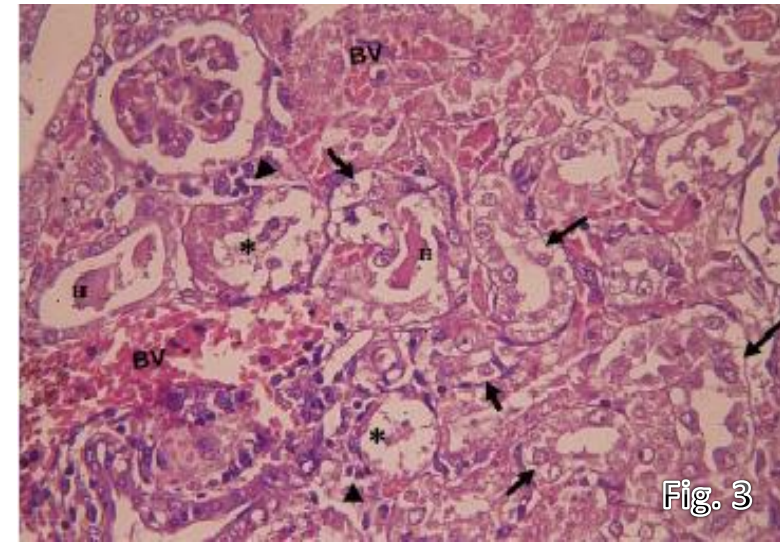

Figure 3: Renal cortex of GM-treated group showing: disruption of the normal structures of the renal cortex and degeneration of proximal and distal convoluted tubules. The lumen of some tubules is obliterated by desquamated cells $(*)$.Vacuolation $(\uparrow)$ and homogenous eosinophilic material are present $(\mathrm{H})$ together with areas of inflammatory cells $(\boldsymbol{\Delta})$ and congested peritubular capillaries (BV). (H\&EX400).

Sections from L-lira-GM group (Group 5) showed distorted cortical structure in the form of loss of the tubular epithelial lining, sloughing of epithelial cells into the lumina

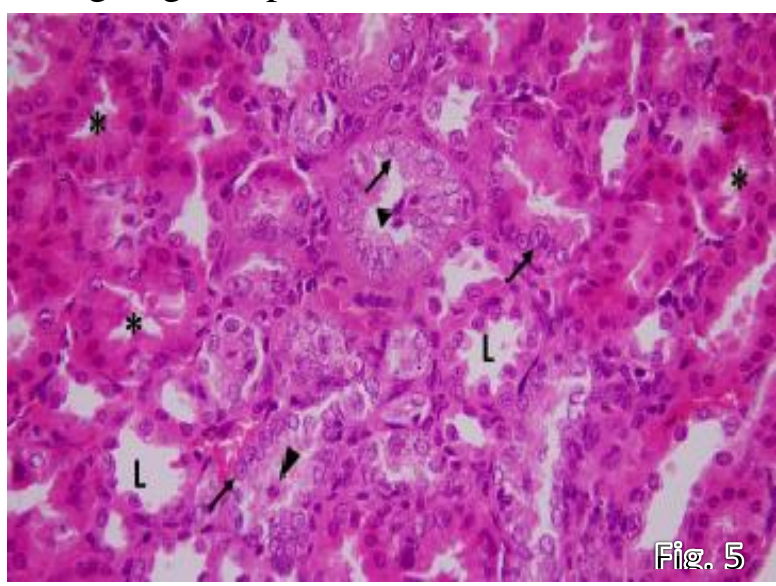

Figure 5: Renal cortex of GM-injected rat pretreated with high dose liraglutide ((H-lira-GM)) showing that most of the tubules have normal cellular lining with large vesicular nuclei $(\uparrow)$, the proximal tubules showed the star shaped lumina (*) similar to the control group. Few tubules are still showing wide lumina lined by slightly separated epithelial cells (L). Few cellular debris are also observed in the lumina of few tubules $(\boldsymbol{\Lambda})$.

(H\&EX400)

On the other hand, histological morphology of the renal cortex of H-lira-

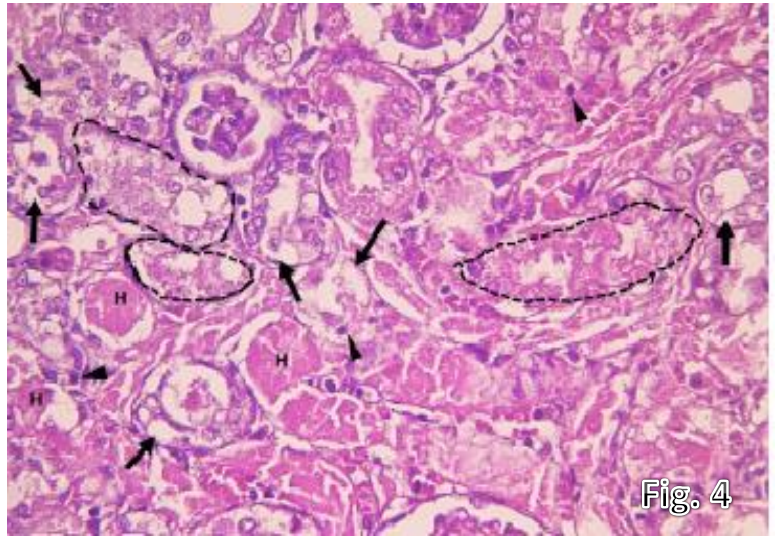

Figure 4: Renal cortex of low dose liraglutide-GMtreated animals ((L-lira-GM)) showing: largely affected structures. The tubules lost their lining epithelium and their lumina are filled with acidophilic hyaline material $(\mathrm{H})$. The tubules are obliterated by cellular debris (black dash line) together with vacuolation of the lining epithelium $(\uparrow)$, and pyknosis $(\boldsymbol{\Delta})(\mathrm{H} \& \mathrm{EXX} 400)$

of the cortical tubules, vacuolation of epithelial cells and dilated congested peritubular capillaries (Figure 4).

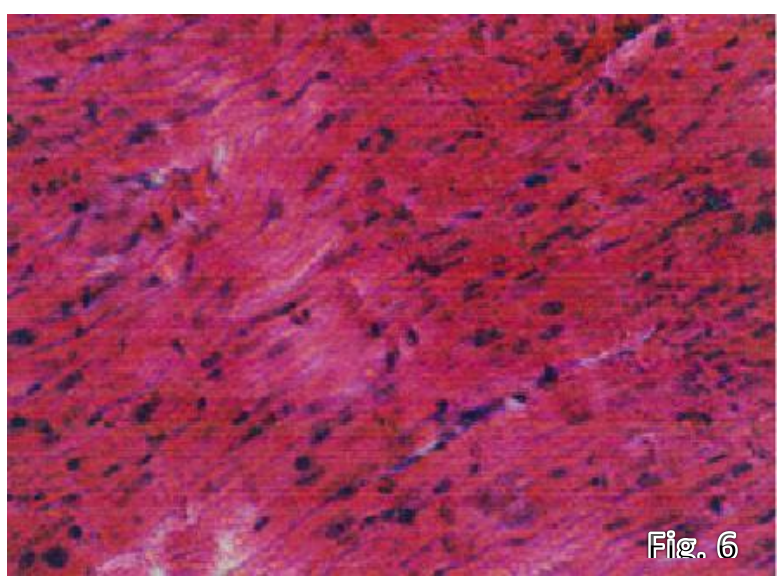

Figure 6: $\mathrm{H}$ and $\mathrm{E}$ stained longitudinal section of the left ventricle of a normal rat showing normal histological features. Normal striations, acidophilic cytoplasm and central fusiform elongated nuclei.

(H\&EX400)

GM group (Group 6) was similar to the control group. The tubules were nearly 
normal with average epithelial lining, normal vesicular nuclei and normal lumina. Other tubules showed star shaped lumina and were lined with deep acidophilic cuboidal epithelium. Few tubules showed slightly separated epithelial cells with little cellular debris (Figure 5).
Hematoxylin and Eosin stained longitudinal sections of the left ventricle of the studied groups:

Control and liraglutide-treated controls (L-lira and H-lira) showed normal histological features as shown in figure 6 and 7.

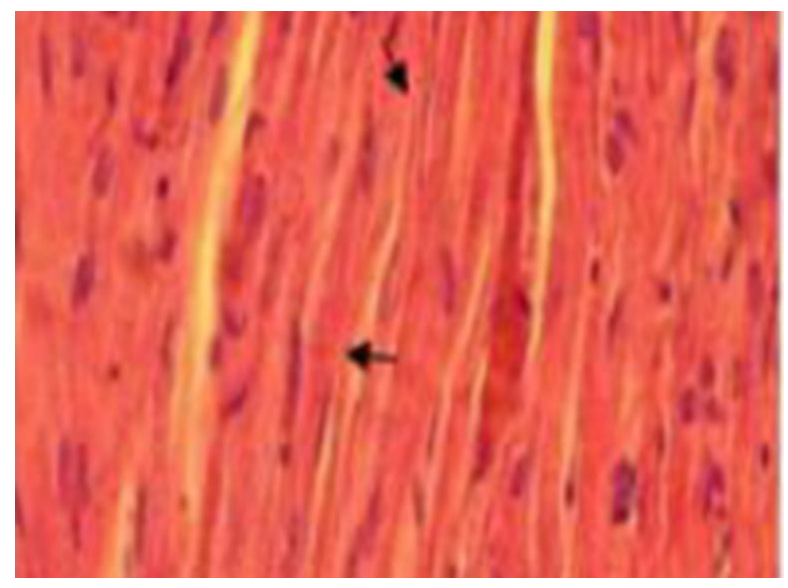

Figure 7: $\mathrm{H}$ and $\mathrm{E}$ stained longitudinal left ventricular section from $\mathrm{H}-$ lira treated group showing normal histological features. Normal striations, acidophilic cytoplasm and central fusiform elongated nuclei.

(H\&EX400)

GM-treated animals showed extensive degeneration of cardiac muscle fibers, which appeared swollen and edematous, with loss of normal arrangement, or nearly absent striations. The sarcoplasm was fragmented,

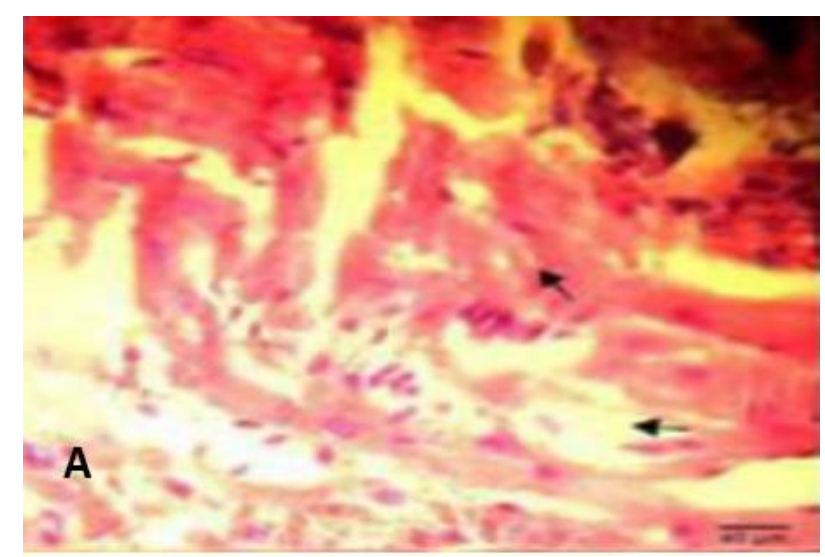

vacuolated and showed marked eosinophilia. Nuclei were degenerated and pyknotic and occasionally absent. Focal areas of hemorrhage and necrosis were evident (Figures 8 a,b,c and d.).

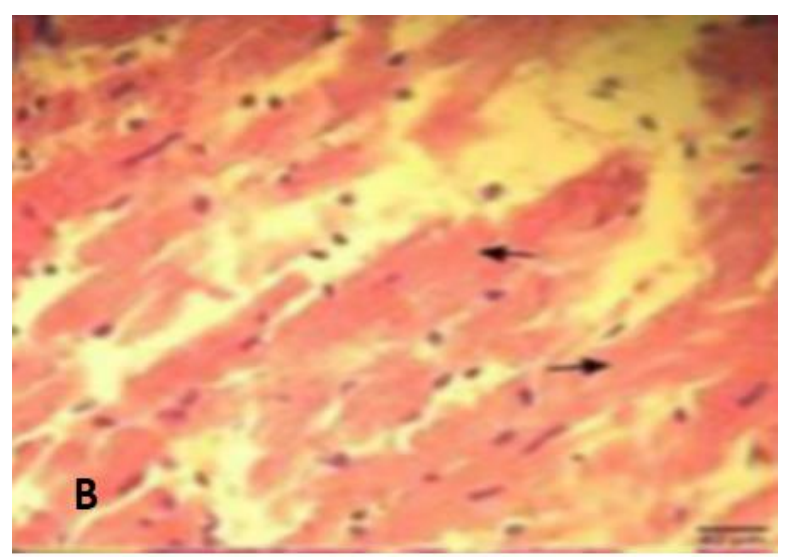


Potential Role Of Glp-1 Receptor Agonist In A Rat Model Of Cardio-Renal Syndrome Type-3: ..
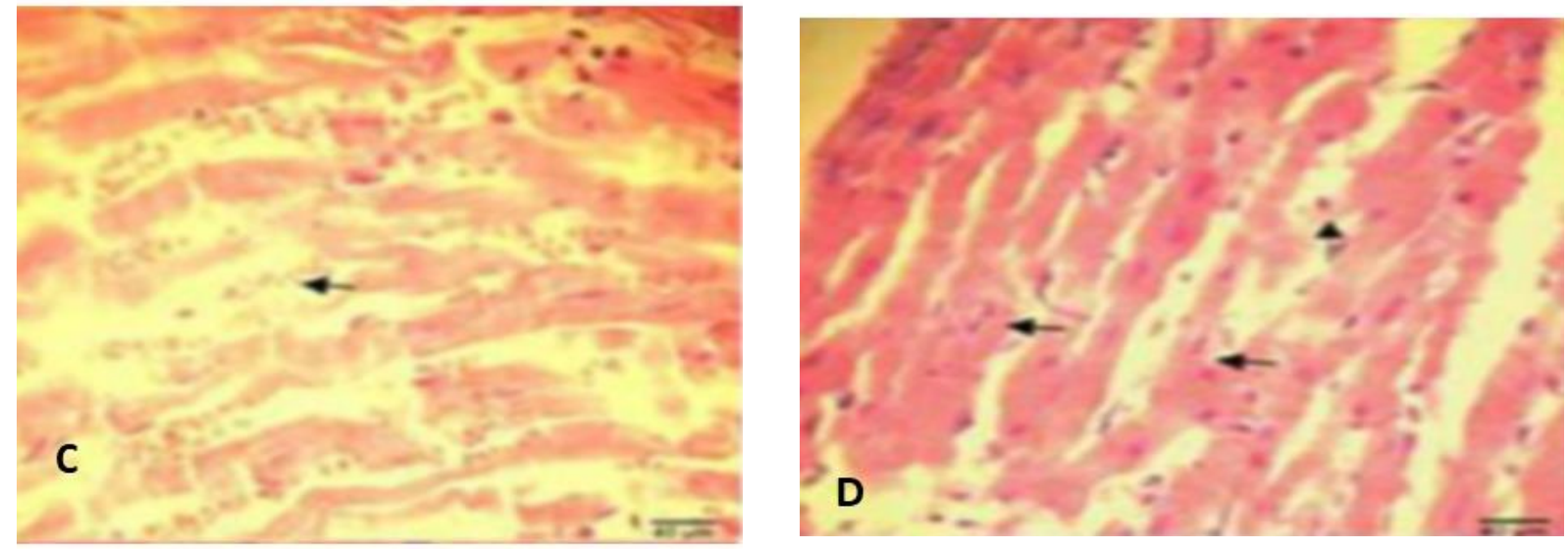

Figure 8: $\mathrm{H}$ and $\mathrm{E}$ stained longitudinal sections of the left ventricle of GM-treated group showing (a) irregularities and loss of striation of the cardiac muscles, (b) hypertrophy and swelling of myofibril, sarcoplasm contains vacuoles with shrunken or degenerating nuclei, (c) multiple focal areas of hemorrhage and necrosis, (d) cardiomyocyte destruction, extremely acidophilic cytoplasm, polymorphic and pyknotic nuclei.

(H\&EX400)

The heart tissue in L-lira-GM group is still showing similar features to rat hearts treated with GM alone. The left ventricular section of hearts of group L-lira-GM showed loss of striations, swollen and edematous fibers, areas of hemorrhage and massive necrosis (Figure 9).

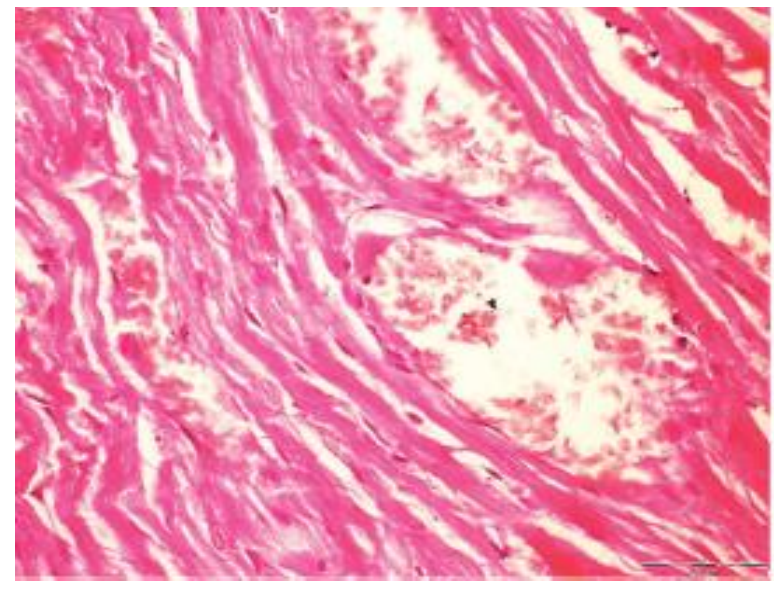

Figure 9: $\mathrm{H}$ and $\mathrm{E}$ stained longitudinal sections of the left ventricle of L-lira-GM treated group. The stained section from left ventricle is still showing irregularities of cardiac muscle fibers, areas of hemorrhage and necrosis, massive eosinophilia and nearly absent nuclei. (H\&EX400)

Histological sections of hearts from $\mathrm{H}$ lira-GM-treated animals showed marked improvement in the histological features almost comparable to those of control rats. The H\&E stained sections of hearts of these rats showed nearly normal striations with normal sarcoplasm. The nuclei were

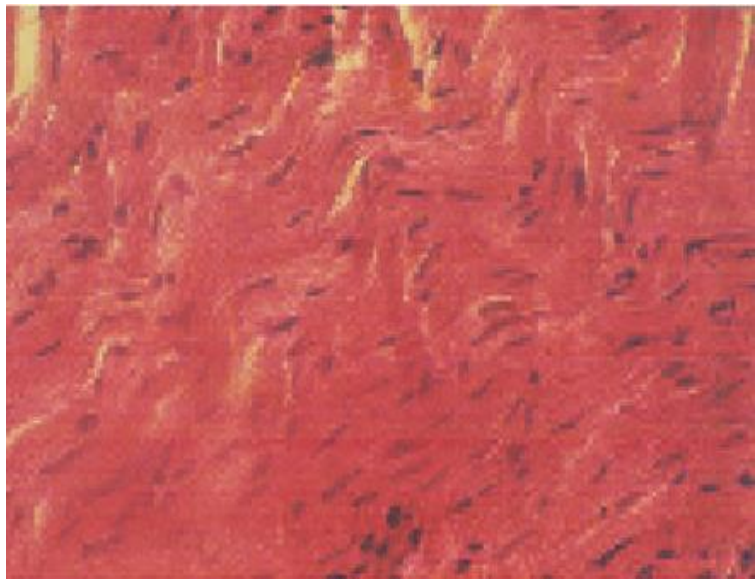

Figure 10: $\mathrm{H}$ and $\mathrm{E}$ stained section from H-liraGM treated group showing marked improvement of myocardial tissues. Myocardial fibers show nearly normal parallel arrangement, average striations, normal central elongated nuclei. Some amounts of connective tissue are still present and little cells show some nuclear polymorphism.

(H\&EX400)

centrally located and vesicular in shape. Connective tissue was still seen more than in sections from control animals (Figure 10).

\section{Biochemical and functional results}

Results of blood glucose, \% change of body weight, and cardiac weights (tables $3 \& 4)$ 
Blood glucose level did not show any significant change among all groups studied. The $\%$ change of body weight was $-7.1 \%$ in GM-treated group as opposed to $8.5 \%$ in the control group. In addition, the $\%$ change in body weight in L-lira-GM group was $-8.3 \%$ nearly similar to $-7.1 \%$ in GM-injected nonliraglutide treatment. In the H-lira-GM group, the body weight showed a percentage change of $8.2 \%$ in contrast to a percentage change of $-7.1 \%$ in GM-injected group

The relative weight of the right ventricle, as well as, the absolute and relative weights of left ventricle (LV), and the whole heart were significantly higher in GM-injected animals when compared to control ones. However, the absolute weight of the right ventricle (RV) of these animals was not significantly different when compared with matched controls. Comparing L-lira-GM to GM-injected group, no significant changes in absolute or relative weights of RV, LV or whole heart were seen. On the other hand, compared to the GM animals, H-lira-GM group showed significant reduction of relative weights of both, left ventricles and whole heart, but no significant change in the absolute and relative weights of right ventricle, and the absolute weights of the left ventricle and the whole heart.

Table 3: Means \pm SD of percent change in body weight (BW) and serum glucose (SG) levels in all groups studied

\begin{tabular}{|l|l|l|l|l|l|l|}
\hline & Control & L-Lira & H-Lira & GM & L-Lira-GM & H-Lira-GM \\
\hline BW(GM) & $8.54 \pm 2.27$ & $7.83 \pm 2.45$ & $6.02 \pm 4.93$ & $-7.47 \pm 4.81$ & $-8.31 \pm 3.87$ & $8.2 \pm 2.11$ \\
\hline SG (mg/dl) & $82 \pm 4.16$ & $83.8 \pm 3.82$ & $79.22 \pm 3.8$ & $79.13 \pm 3.04$ & $80.11 \pm 6.17$ & $78.56 \pm 6.54$ \\
\hline
\end{tabular}

${ }^{*} \mathrm{P}<0.05$ significant from control group. ${ }^{* *} \mathrm{P}<0.05$ significant from GM group.

Table 4: Means \pm SD of the weights of the right ventricle (RV), left ventricle (LV) and the whole heart (WH) expressed as absolute weights and relative to the body weights

\begin{tabular}{|l|l|l|l|l|l|l|}
\hline & Control & L-Lira & H-Lira & GM & L-Lira-GM & H-Lira-GM \\
\hline RV(mg) & $102.3 \pm 12.2$ & $111.60 \pm 14.50$ & $101.33 \pm 16.85$ & $101 \pm 15.69$ & $111.2 \pm 17.09$ & $111.22 \pm 14$ \\
RV/BW & $0.42 \pm 0.04$ & $0.45 \pm .06$ & $0.44 \pm 0.07$ & $0.48^{*} \pm 0.07$ & $0.53 \pm 0.09$ & $0.46 \pm 0.06$ \\
\hline LV(mg) & $475.70 \pm 42.47$ & $503.60 \pm 45.64$ & $461.67 \pm 46.53$ & $543.6 * \pm 82.16$ & $500.67 \pm 55.62$ & $503.44 \pm 48.41$ \\
LV/BW & $1.96 \pm 0.17$ & $2.03 \pm 0.18$ & $2.01 \pm 0.25$ & $2.61^{*} \pm 0.55$ & $2.39 \pm 0.31$ & $0.2 .07 * * \pm 0.22$ \\
\hline WH (mg) & $660.7 \pm 68.16$ & $706 \pm 59.06$ & $643.44 \pm 60.81$ & $750^{*} \pm 91.96$ & $692.33 \pm 91.28$ & $709 \pm 61.57$ \\
WH/BW & $2.72 \pm 0.30$ & $2.84 \pm 0.24$ & $2.81 \pm 0.33$ & $3.61^{*} \pm 0.73$ & $3.3 \pm 0.44$ & $2.92^{* *} \pm 0.30$ \\
\hline
\end{tabular}

$* \mathrm{P}<0.05$ significant from control group. $* * \mathrm{P}<0.05$ significant from GM group.

\section{Serum levels of renal and cardiac biomarkers (figures 11-15):}

GM-treated rats showed significant increase in serum urea and creatinine when compared to their matching controls. Serum urea and creatinine in GM-treated animals pretreated with low dose of liraglutide were not significantly different from their levels in the GM-treated group. On the other hand, animals of the same group pretreated with high dose liraglutide showed a significant drop in their serum urea and creatinine when compared with the GM-treated group (Figure 11 and 12). 


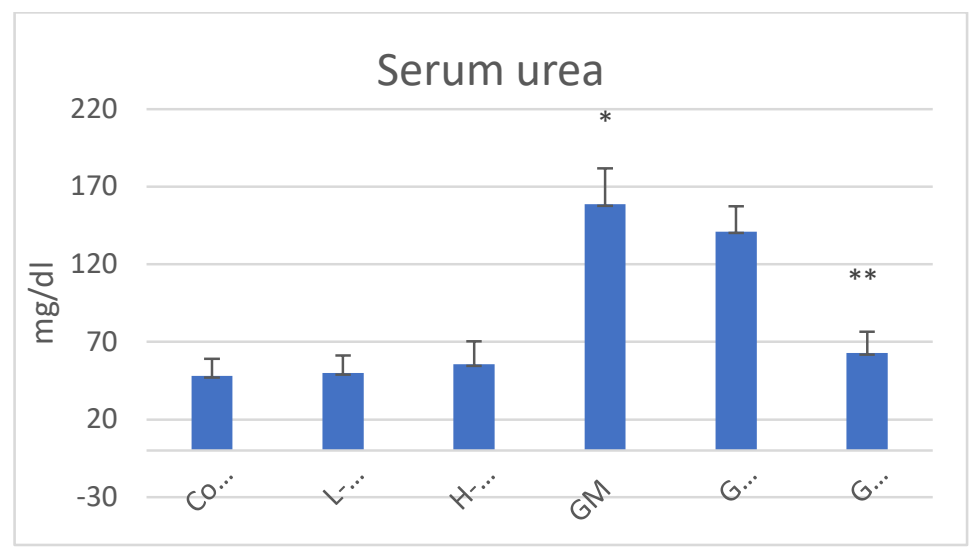

Figure 11: Effects of low and high doses of liraglutide pretreatment on serum urea of normal and GM-treated groups. Values are expressed as mean $+\mathrm{SD}$. ${ }^{*} \mathrm{P}<0.05$ significant from control group $(\mathrm{C}),{ }^{*} \mathrm{P}<0.05$ significant from GM-treated group.

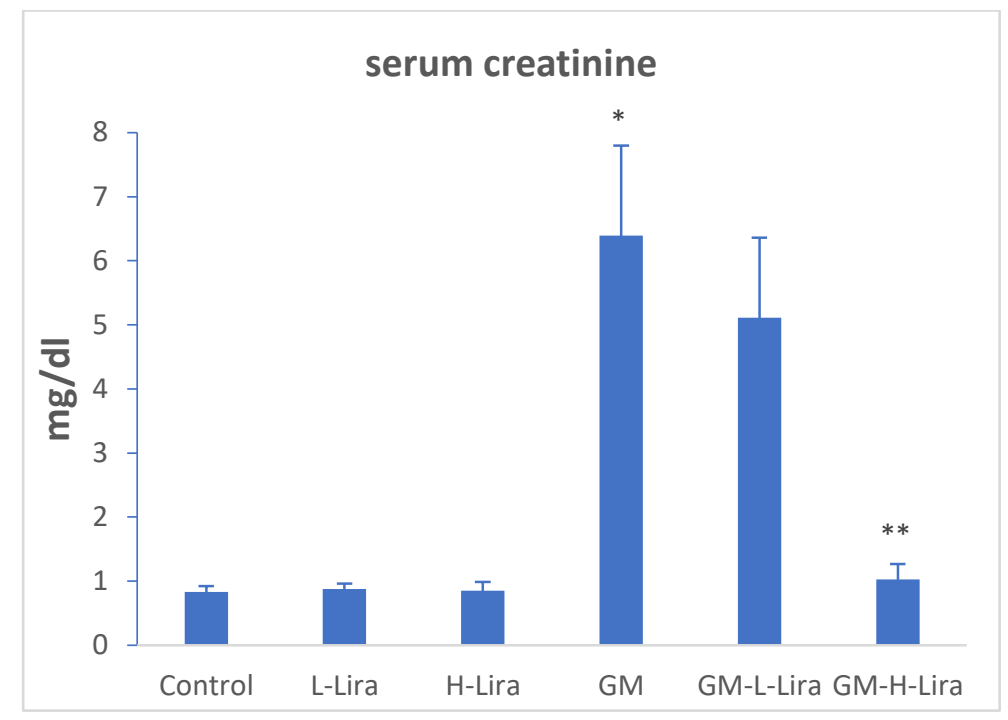

Figure 12: Effects of low and high doses of liraglutide pretreatment on serum creatinine of normal and GMtreated groups. Values are expressed as mean $+\mathrm{SD}$. $* \mathrm{P}<0.05$ significant from control group. ${ }^{* *} \mathrm{P}<0.05$ significant from GM group.

GM-treated rats showed significant elevation of serum troponin I (TnI), creatine kinase (CK-MB), and lactate dehydrogenase $(\mathrm{LDH})$ when compared to their matching controls. These parameters were not significantly different in animals pretreated with low dose of liraglutide, when compared with the GM-treated group. On the other hand, TnI, CK-MB and LDH were significantly lower in GM-treated animals pretreated with high dose liraglutide when compared with the GM-treated group (Figures 13-15). 


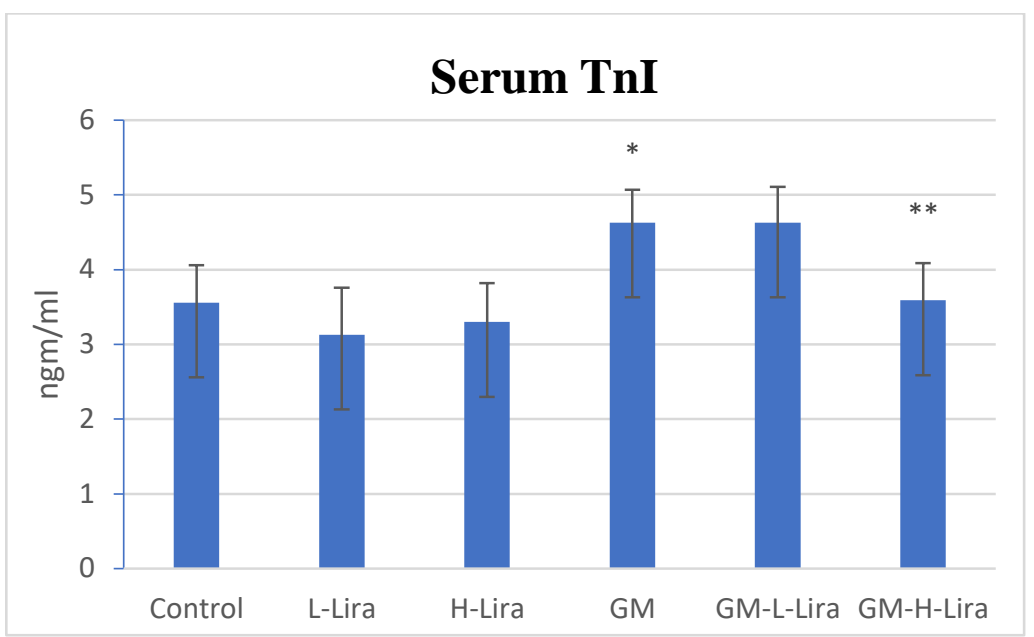

Figure 13: Effects of low and high doses of liraglutide pretreatment on serum TnI of normal and GM-treated groups. Values are expressed as mean $+\mathrm{SD} .{ }^{*} \mathrm{P}<0.05$ significant from control group. ${ }^{*} \mathrm{P}<0.05$ significant from GM group.

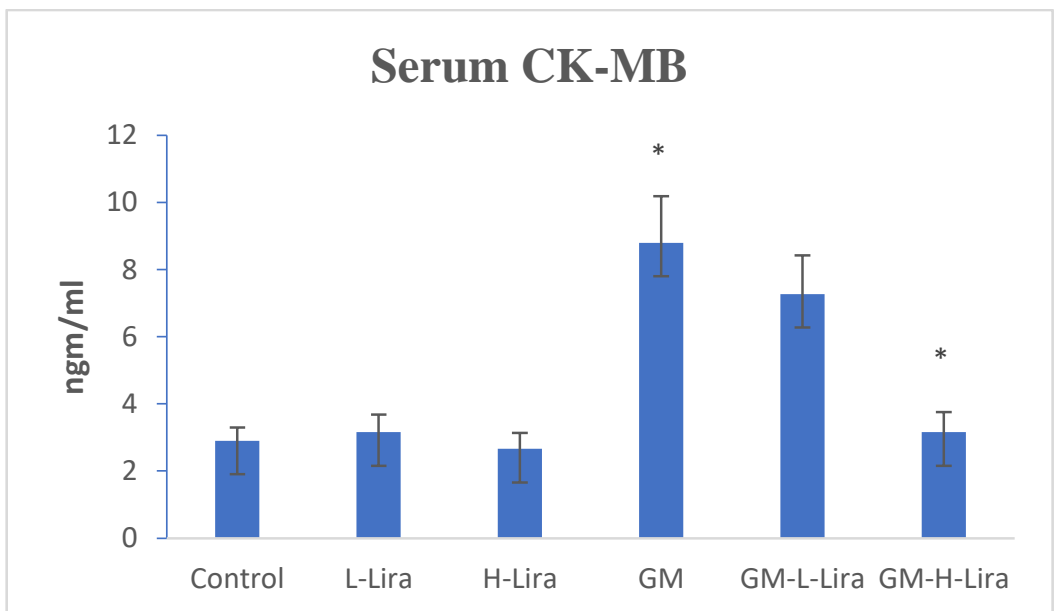

Figure 14: Effects of low and high doses of liraglutide pretreatment on serum CK-MB of normal and GM-treated groups. Values are expressed as mean $+\mathrm{SD} . * \mathrm{P}<0.05$ significant from control group. ${ }^{*} \mathrm{P}<0.05$ significant from GM group.

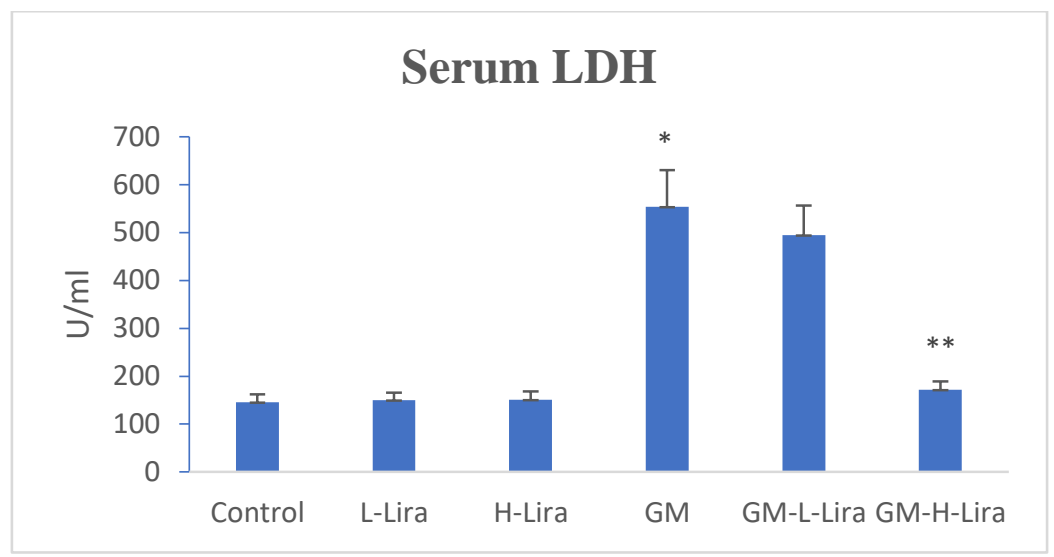

Figure 15: Effect of low and high doses of liraglutide pretreatment on serum LDH of normal and GM-treated groups. Values are expressed as mean $+\mathrm{SD} .{ }^{*} \mathrm{P}<0.05$ significant from control group. ${ }^{*} \mathrm{P}<0.05$ significant from GM group. 
Cardiac functions and ECG (table 5):

There was a significant increase in mean systolic blood pressure and significant drop of heart rate of GM-treated group when compared with the control group, Moreover, the GM-treated animals showed significant increase in the T-wave voltage, as well as significant increase in both Q-T and Q-Tc when compared with control group. Animals pretreated with low dose liraglutide were not significantly different from their non-treated counterparts in the GM group. On the other hand, pretreatment of GM group with high dose liraglutide significantly lowered the

Table 5: Means \pm SD of systolic blood pressure (SBP), heart rate (HR), and ECG parameters in the studied groups

\begin{tabular}{|l|c|c|c|c|c|c|c|}
\hline & $\begin{array}{c}\text { SBP } \\
(\mathrm{mmH})\end{array}$ & $\begin{array}{c}\text { HR } \\
(\mathrm{bpm})\end{array}$ & $\begin{array}{c}\text { QRS } \\
(\mathrm{sec})\end{array}$ & $\begin{array}{c}\text { Rvoltage } \\
(\text { mvolt })\end{array}$ & $\begin{array}{c}\text { T voltage } \\
(\mathrm{mvolt})\end{array}$ & $\begin{array}{c}\text { Q-tT } \\
(\mathrm{sec})\end{array}$ & $\begin{array}{c}\text { Q-Tc } \\
(\mathrm{sec})\end{array}$ \\
\hline Control & 135 & 365.5 & 0016 & 0.76 & 0.205 & 0.073 & 0.180 \\
& \pm 6.24 & \pm 21.28 & \pm .005 & \pm .08 & \pm 0.04 & \pm 0.01 & \pm .027 \\
\hline L-Lira & 139 & 374.5 & 0.018 & 0.725 & 0.2 & 0.076 & 0.190 \\
& \pm 7.38 & \pm 17.23 & \pm 0.005 & \pm 0.10 & \pm 0.04 & \pm 0.01 & \pm 0.025 \\
\hline H-Lira & 138.3 & 370.6 & 0.017 & 0.761 & 0.189 & 0.073 & 0.183 \\
& \pm 7.07 & \pm .25 .3 & \pm 0.006 & \pm 0.08 & \pm 0.05 & \pm 0.01 & \pm 0.03 \\
\hline GM & $146.3 *$ & $334.4^{*}$ & $0.021^{*}$ & 0.713 & $0.269 *$ & $0.094^{*}$ & $0.222^{*}$ \\
& \pm 13.56 & \pm 25.28 & \pm 0.004 & \pm 0.07 & \pm 0.05 & \pm 0.02 & \pm 0.05 \\
\hline L-Lira-GM & 136.1 & 361.7 & 0.018 & 0.73 & 0.222 & 0.079 & 0.0 .194 \\
& \pm 7.82 & \pm 28.06 & \pm 0.006 & \pm 0.1 & \pm 0.04 & \pm 0.01 & \pm 0.03 \\
\hline H-Lira-GM & $131 * *$ & $367.2 * *$ & $0.015 * *$ & 0.733 & $0.211^{* *}$ & $0.074 * *$ & $0.183 * *$ \\
& \pm 7.5 & \pm 30.32 & \pm 0.006 & \pm 0.1 & \pm 0.05 & \pm 0.009 & \pm 0.022 \\
\hline
\end{tabular}

$* \mathrm{P}<0.05$ significant from control group. $* * \mathrm{P}<0.05$ significant from GM group.
Results of MDA, NO and antioxidant indices (figures 6-10 and table 6):

GM injection of rats was associated with a significant increase in serum MDA and NO in addition to their increase in renal and cardiac tissues, when compared to normal rats. Furthermore, a significant decrease of SOD in serum and GSH, and catalase activity in serum, renal and cardiac tissues of GM-injected animals was found when compared to control group. The previous parameters were not significantly mean systolic blood pressure and significantly increased the heart rate when compared with GM-treated. Similarly, pretreatment of GM group with low dose liraglutide did not show statistically significant changes in all measured ECG parameters when compared with non-treated control animals. High dose liraglutide pretreatment of GM-injected rats, however, was associated with significant decrease of QRS duration, T-wave voltage and significant decrease in both Q-T and Q-Tc when compared with GM-injected animals. changed in in GM-treated rats when pretreated with low dose liraglutide.

On the other hand, pretreatment of GMtreated rats with high dose liraglutide resulted in significant drop of MDA and NO in serum as well as in both renal and cardiac tissues when compared to GM group. Significant increase was found in SOD in serum and GSH, and catalase activity in serum, renal and cardiac tissues in rats pretreated with high dose liraglutide before GM injection as compared to rats treated with GM alone. 


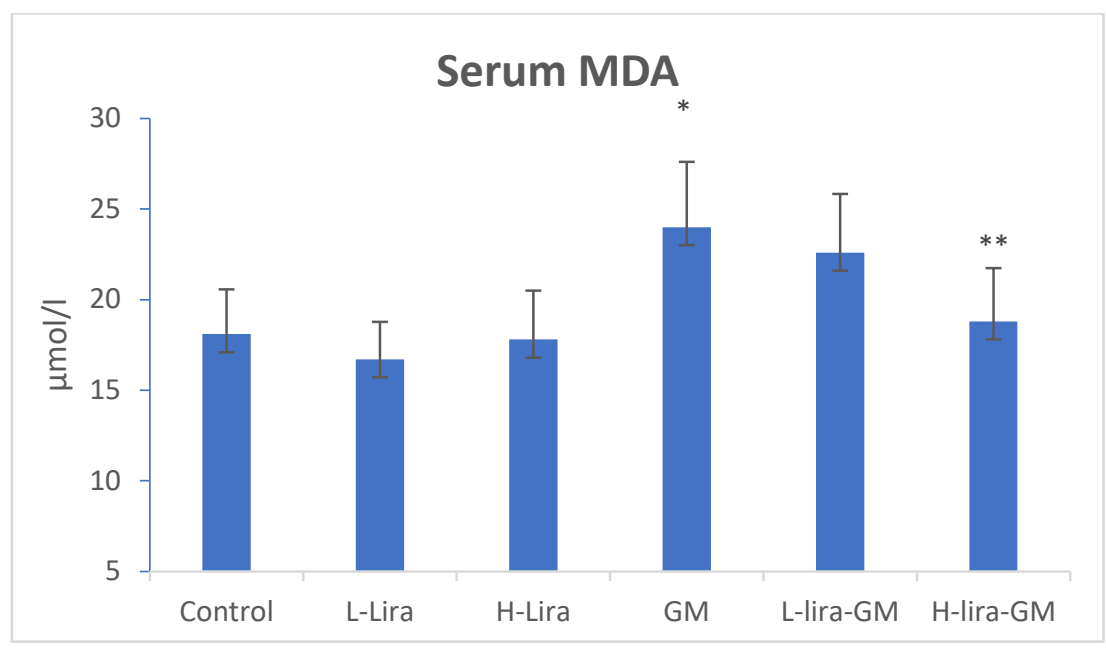

Figure 16: Effects of low and high doses of liraglutide pretreatment on serum MDA of normal and GMtreated groups. Values are expressed as mean $+\mathrm{SD} .{ }^{*} \mathrm{P}<0.05$ significant from control group. $* * \mathrm{P}<0.05$ significant from GM group.

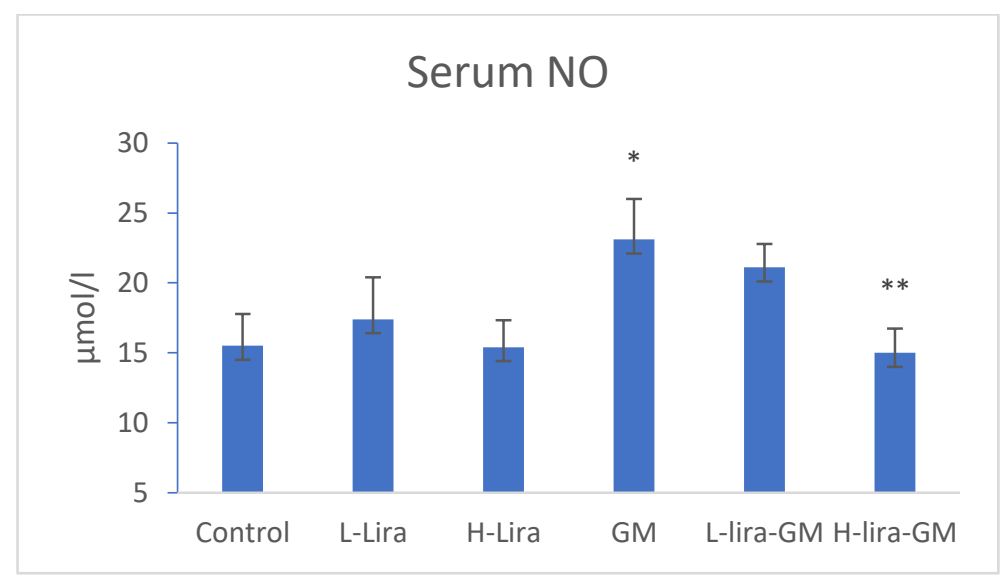

Figure 17: Effects of low and high doses of liraglutide pretreatment on serum NO of normal and GM-treated groups. Values are expressed as mean $+\mathrm{SD}$. $* \mathrm{P}<0.05$ significant from control group. $* * \mathrm{P}<0.05$ significant from GM group.

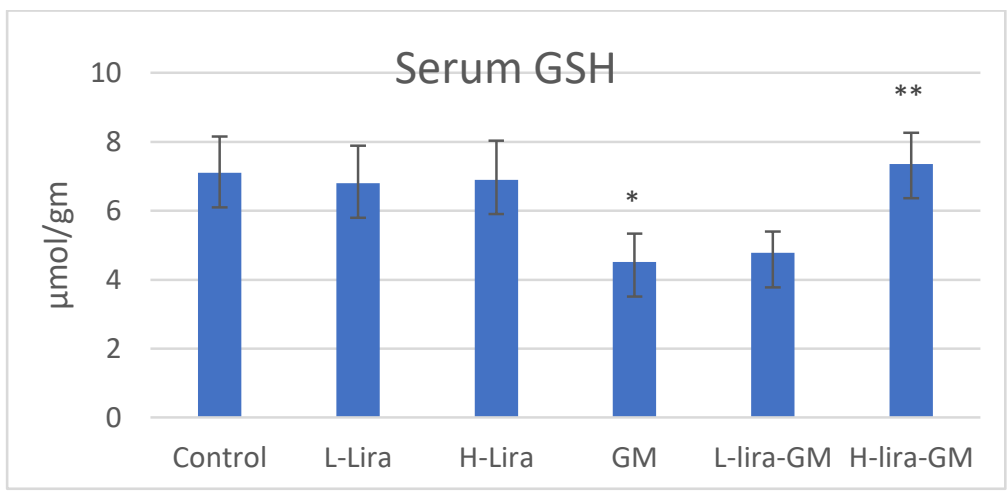

Figure 18: Effects of low and high doses of liraglutide pretreatment on serum GSH of normal and GM-treated groups. Values are expressed as mean $+\mathrm{SD} . * \mathrm{P}<0.05$ significant from control group. $* * \mathrm{P}<0.05$ significant from GM group. 


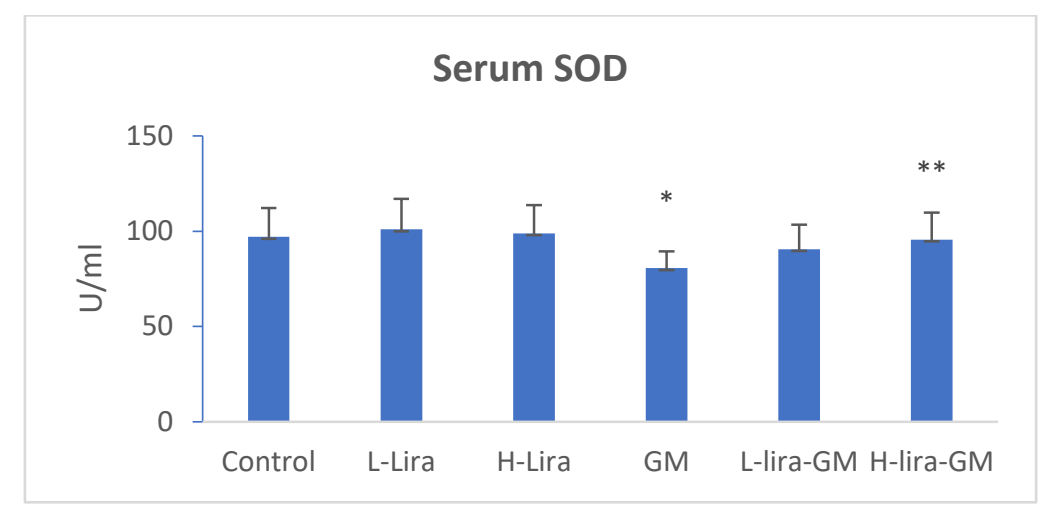

Figure 19: Effects of low and high doses of liraglutide pretreatment on serum SOD of normal and GM-treated groups. Values are expressed as mean $+\mathrm{SD}$. ${ }^{*} \mathrm{P}<0.05$ significant from control group. $* * \mathrm{P}<0.05$ significant from GM group.

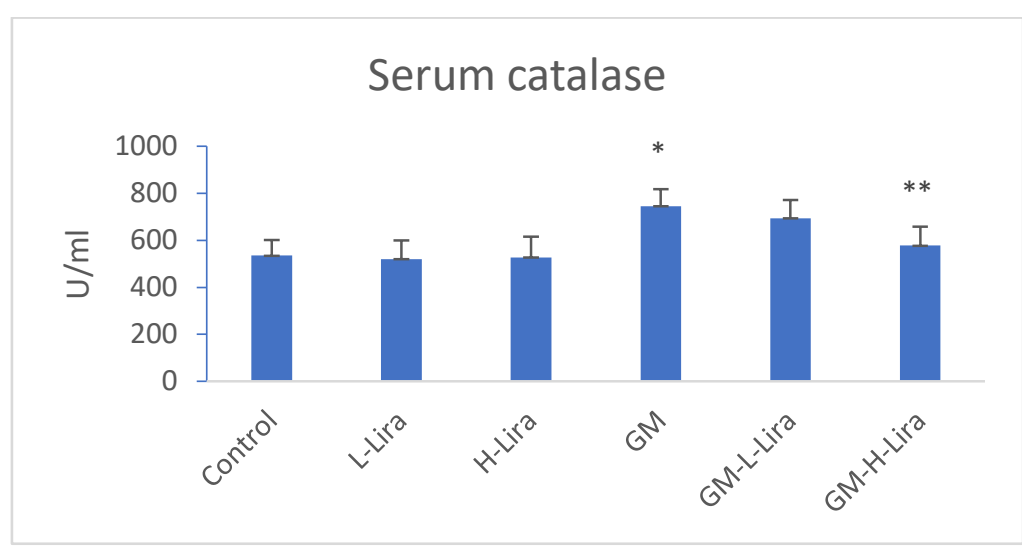

Figure 20: Effects of low and high doses of liraglutide pretreatment on serum catalase of normal and GM-treated groups. Values are expressed as mean $+\mathrm{SD} .{ }^{*} \mathrm{P}<0.05$ significant from control group. $* * \mathrm{P}<0.05$ significant from GM group.

Table 6: The means \pm SD of malondialdehyde (MDA), nitric oxide (NO), reduced glutathione $(\mathrm{GSH})$ and catalase enzyme in the renal and cardiac tissues of the studied groups

\begin{tabular}{|c|c|c|c|c|c|}
\hline & & $\begin{array}{l}\text { MDA } \\
(\mu \mathrm{mol} / \mathrm{gm})\end{array}$ & $\begin{array}{l}\text { NO } \\
(\mu \mathrm{mol} / \mathrm{gm})\end{array}$ & $\begin{array}{l}\text { GSH } \\
(\mu \mathrm{mol} / \mathrm{g})\end{array}$ & Catalase (U/gm) \\
\hline Control & $\begin{array}{ll} & \\
-\quad & \text { Renal } \\
\text { - } & \text { Cardiac }\end{array}$ & $\begin{array}{l}5.4 \pm 0.97 \\
3.4 \pm 0.86\end{array}$ & $\begin{array}{l}20.2 \pm 2.53 \\
15.7 \pm 2.21\end{array}$ & $\begin{array}{l}5.49 \pm 0.58 \\
3.45 \pm 0.47\end{array}$ & $\begin{array}{l}13.9 \pm 2.33 \\
6 \pm 1.63\end{array}$ \\
\hline L-Lira & $\begin{array}{ll} & \\
-\quad & \text { Renal } \\
\text { - } & \text { Cardiac }\end{array}$ & $\begin{array}{l}4.4 \pm 1.26 \\
3.16 \pm 0.79\end{array}$ & $\begin{array}{l}19.7 \pm 1.95 \\
16.6 \pm 1.90\end{array}$ & $\begin{array}{l}5.06 \pm 0.57 \\
3.56 \pm 0.58\end{array}$ & $\begin{array}{l}13.4 \pm 2.12 \\
6.4 \pm 1.71\end{array}$ \\
\hline H-Lira & $\begin{array}{ll} & \\
\text { - } & \text { Renal } \\
\text { Cardiac }\end{array}$ & $\begin{array}{l}5.44 \pm 1.01 \\
3.44 \pm 0.88\end{array}$ & $\begin{array}{l}20.67 \pm 2.18 \\
16.11 \pm 3.33\end{array}$ & $\begin{array}{l}5.38 \pm 0.66 \\
3.18 \pm 0.59\end{array}$ & $\begin{array}{l}14.11 \pm 2.37 \\
6.22 \pm 1.56\end{array}$ \\
\hline GM & $\begin{array}{ll} & \\
-\quad & \text { Renal } \\
-\quad & \text { Cardiac }\end{array}$ & $\begin{array}{l}7.83 \pm 1.80^{*} \\
5.30 \pm 0.71^{*}\end{array}$ & $\begin{array}{l}26.22 \pm 3.27 * \\
22.6 \pm 3.05 *\end{array}$ & $\begin{array}{l}3.31 \pm 0.46^{*} \\
27.2 \pm 3.23^{*}\end{array}$ & $\begin{array}{l}10.89 \pm 1.76^{*} \\
4.21 \pm 0.67 *\end{array}$ \\
\hline L-Lira-G & $\begin{array}{ll}\text { GM } & \\
\bullet & \text { Renal } \\
- & \text { Cardiac }\end{array}$ & $\begin{array}{l}6.6 \pm 0.55 \\
4.96 \pm 0.76\end{array}$ & $\begin{array}{l}23.7 \pm 3.08 \\
21.2 \pm 2.82\end{array}$ & $\begin{array}{l}3.52 \pm 0.54 \\
2.92 \pm 0.39\end{array}$ & $\begin{array}{l}11.89 \pm 2.03 \\
4.86 \pm 0.75\end{array}$ \\
\hline H-Lira-C & $\begin{array}{ll}\text { GM } & \\
\bullet & \text { Renal } \\
\bullet & \text { Cardiac }\end{array}$ & $\begin{array}{l}5.67 \pm 1.12 * \\
3.74 \pm 0.69 *\end{array}$ & $\begin{array}{l}20.11 \pm 2.57 * * \\
17.8 \pm 2.82 * *\end{array}$ & $\begin{array}{l}5.21 \pm 0.62 * * \\
3.32 \pm 0.44 * *\end{array}$ & $\begin{array}{l}14.2 \pm 1.39 * * \\
6.13 \pm 1.13 * *\end{array}$ \\
\hline
\end{tabular}

$* \mathrm{P}<0.05$ significant from control group. ${ }^{*} \mathrm{P}<0.05$ significant from $\mathrm{GM}$ group. 
Pro-inflammatory cytokines and iNOS mRNA (Figures 21-25 and table 7):

GM injection of rats was associated with significant increase in TNF- $\alpha$, IL- $1 \beta$ and IL-6 in plasma, and renal and cardiac tissues, on comparison with normal control rats. Comparing the low dose liraglutidetreated GM-injected animals with GM- injected matched controls, did not reveal any statistical differences in TNF- $\alpha$, IL-1 $\beta$ and IL-6 in serum, renal or cardiac tissue homogenates. The high dose liraglutide pretreatment of GM-group resulted in significant drop of TNF- $\alpha$, IL-1 $\beta$, IL-6 when compared with GM animals non-treated with liraglutide (Figures 6,7 and table 6)

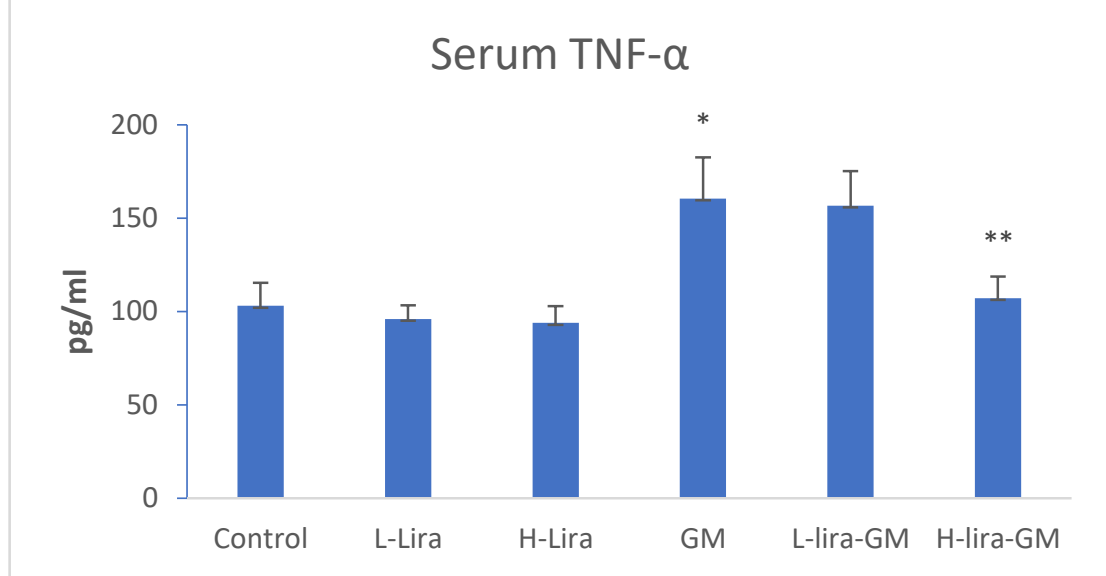

Figure 21: Effects of low and high doses of liraglutide pretreatment on serum TNF- $\alpha$ of normal and GM-treated groups. Values are expressed as mean $+\mathrm{SD} .{ }^{*} \mathrm{P}<0.05$ significant from control group. ${ }^{*} * \mathrm{P}<0.05$ significant from GM group.

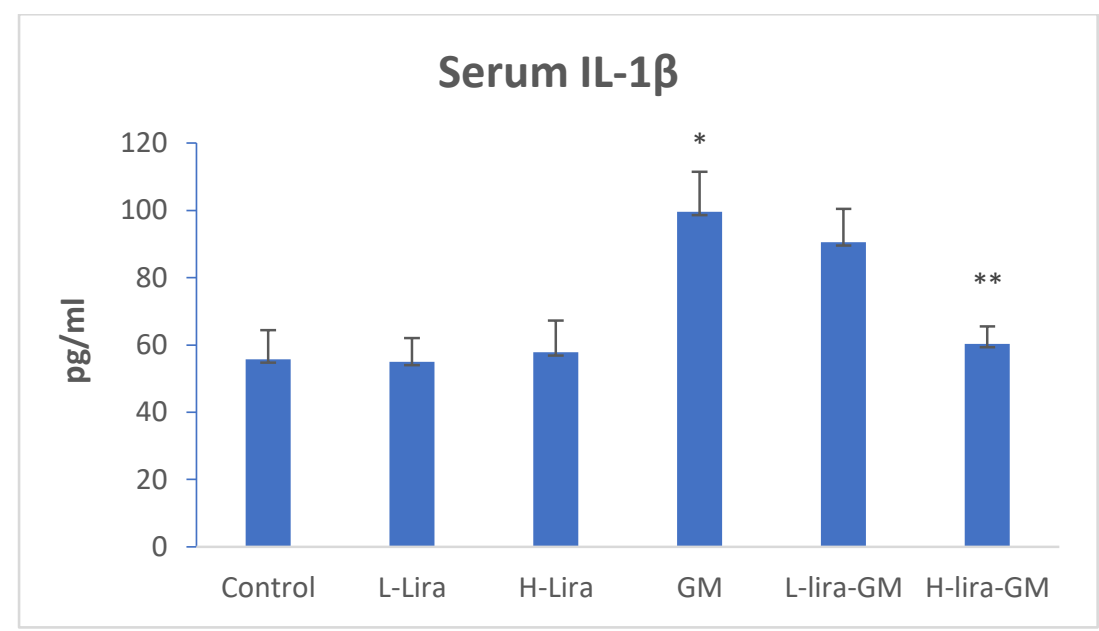

Figure 22: Effects of low and high doses of liraglutide pretreatment on serum IL-1 $\beta$ of normal and GM-treated groups. Values are expressed as mean $+\mathrm{SD} .{ }^{*} \mathrm{P}<0.05$ significant from control group. ${ }^{*} \mathrm{P}<0.05$ significant from GM group. 


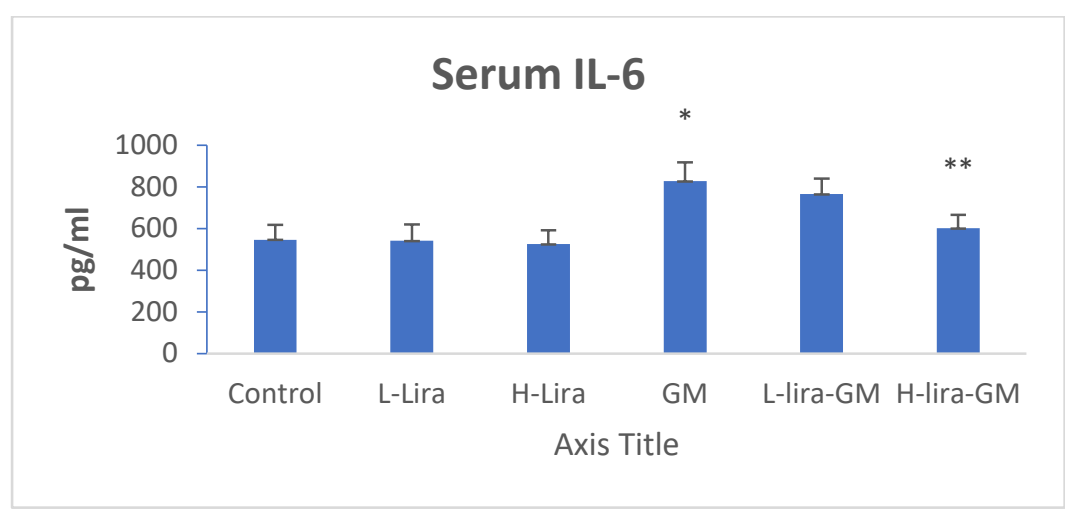

Figure 23: Effects of low and high doses of liraglutide pretreatment on serum IL-6 of normal and GM-treated groups. Values are expressed as mean $+\mathrm{SD} .{ }^{*} \mathrm{P}<0.05$ significant from control group. ${ }^{*} \mathrm{P}<0.05$ significant from GM group.

The level of iNOS expression in renal and cardiac tissues was significantly higher in GM-injected animals, compared to control ones. Pretreatment with low dose liraglutide did not show significant change when compared with GM-non-liraglutide treated

animals. However, pretreatment with high dose liraglutide of GM-injected group showed significant drop in the level of iNOS expression in both renal and cardiac tissues, when compared with GM group not treated with liraglutide (Figures 24 and 25).

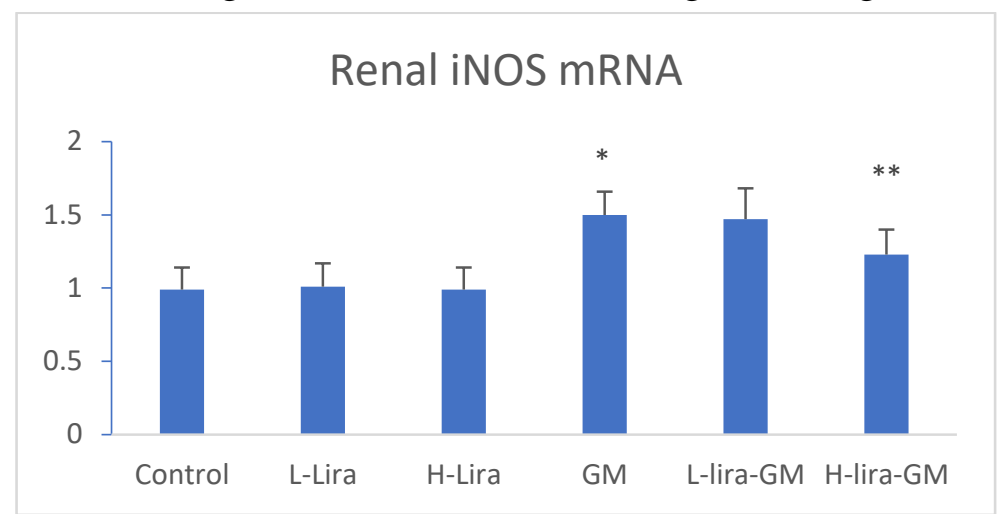

Figure 24: Effects of low and high doses of liraglutide pretreatment on renal iNOS mRNA in renal tissue of normal and GM-treated groups. Values are expressed as mean $+\mathrm{SD}$. ${ }^{*} \mathrm{P}<0.05$ significant from control group. $* * \mathrm{P}<0.05$ significant from GM group

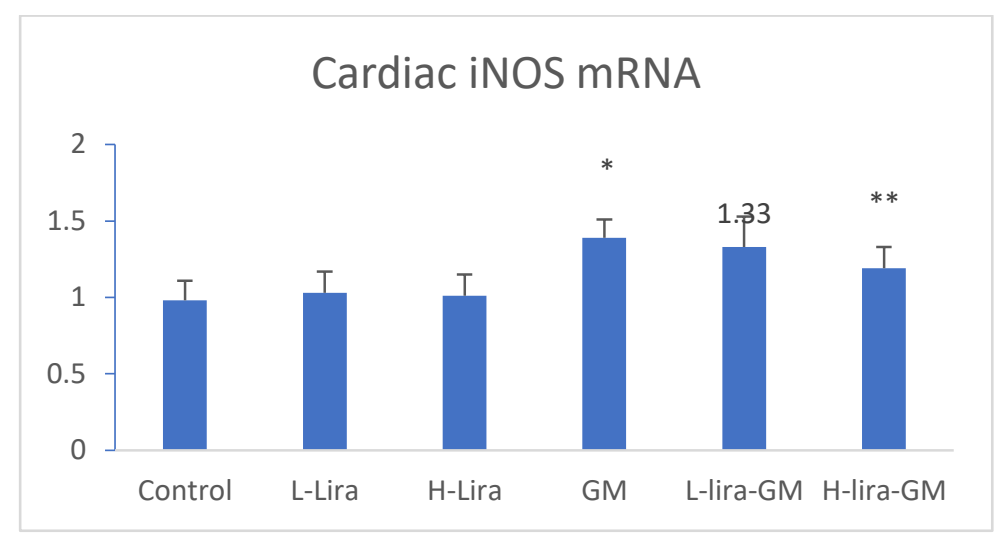

Figure 25: Effects of low and high doses of liraglutide pretreatment on cardiac iNOS mRNA in renal tissue of normal and GM-treated groups. Values are expressed as mean $+\mathrm{SD}$. $* \mathrm{P}<0.05$ significant from control group. $* * \mathrm{P}<0.05$ significant from GM group 
Table 7: The means \pm SD of TNF- $\alpha$, IL-1 $\beta$ and IL-6 content of renal and cardiac tissues of animals in the studied groups.

\begin{tabular}{|c|c|c|c|c|}
\hline & & $\begin{array}{l}\text { TNF- } \alpha \\
\text { (pg/ml) }\end{array}$ & IL-1及 (pg/ml) & $\begin{array}{l}\text { IL-6 } \\
(\mathrm{pg} / \mathrm{ml})\end{array}$ \\
\hline L-Lira & $\begin{array}{ll} & \text { Renal } \\
\text { - } & \text { Cardiac }\end{array}$ & $\begin{array}{l}158 \pm 18.3 \\
127 \pm 7.25\end{array}$ & $\begin{array}{l}62.5 \pm 7.9 \\
43.2 \pm 4.98\end{array}$ & $\begin{array}{l}411 \pm 37.25 \\
374 \pm 46.50\end{array}$ \\
\hline H-Lira & $\begin{array}{ll} & \text { Renal } \\
\text { - } & \text { Cardiac }\end{array}$ & $\begin{array}{l}151.8 \pm 15.2 \\
128.8 \pm 11.67\end{array}$ & $\begin{array}{l}62.2 \pm 9.72 \\
41.6 \pm 4.50\end{array}$ & $\begin{array}{l}419 \pm 51.40 \\
403.0 \pm 51.0\end{array}$ \\
\hline GM & $\begin{array}{ll} & \\
\text { - } & \text { Renal } \\
\text { Cardiac }\end{array}$ & $\begin{array}{l}205.6+15.9 \\
153.3 \pm 9.75^{*}\end{array}$ & $\begin{array}{l}93 \pm 9.14^{*} \\
57.3 \pm 5.06^{*}\end{array}$ & $\begin{array}{l}600 \pm 53.1 * \\
469 \pm 59.22^{*}\end{array}$ \\
\hline L-Lira-C & $\begin{array}{ll}\text { GM } & \\
\bullet \quad & \text { Renal } \\
\text { - } & \text { Cardiac }\end{array}$ & $\begin{array}{l}208.3 \pm 18.54 \\
138.3 \pm 19.25\end{array}$ & $\begin{array}{l}85.5 \pm 6.74 \\
50.3 \pm 7.09\end{array}$ & $\begin{array}{l}560 \pm 70.4 \\
432 \pm 47.64\end{array}$ \\
\hline H-Lira- & $\begin{array}{ll}\text { GM } \\
\text { - } \quad \text { Renal } \\
\text { - Cardiac }\end{array}$ & $\begin{array}{l}188.9 \pm 10.78 * * \\
130.6 \pm 13.57 * *\end{array}$ & $\begin{array}{l}69.9 \pm 8.52^{* *} \\
45.1 \pm 5.84^{* *}\end{array}$ & $\begin{array}{l}476 \pm 58.3 * * \\
371 \pm 42.06 * *\end{array}$ \\
\hline
\end{tabular}

\section{DISCUSSION:}

GM-induced nephrotoxicity is a wellknown animal model for $\mathrm{AKI}^{(27)}$. The present study demonstrated elevated serum urea and creatinine levels, in addition to histopathological alterations in the renal cortex of GM-injected rats. These findings are well known evidences of GM-induced acute renal injury ${ }^{(20,28)}$. Renal damage demonstrated in the histopatholgical sections pointed to a marked injury to parenchyma cells that leads to depressed glomerular filtration and ultrafiltration ${ }^{(29)}$. The induced loss of renal integrity and function, thus, underlies the accumulation of creatinine and urea in the blood shown in this study.

Moreover, the GM-induced AKI caused cardiovascular dysfunction represented in higher blood pressure, lower heart rate, cardiac hypertrophy, and ECG abnormalities. These findings are in line with previous observations of disturbances in cardiac functions in the setting of $\mathrm{AKI}^{(4,30)}$. Bradycardia shown in the data of GM-injected rats in the current study reflects depressed cardiac functions. Elevated blood pressure reported in our study indicates hemodynamic changes that occur in conditions of cardio-renal syndrome type $3^{(31)}$. The prolongation of QT interval and QTc as well as QRS duration among our ECG findings in GM nephrotoxic rats could be considered early indicators of myocardial infarction development ${ }^{(32) \text {. }}$

The significant elevation of serum CK$\mathrm{MB}$, cardiac TnI and LDH activity further potentiated the distant myocardial injury in this work. These biomarkers have been largely considered as indicators of acute myocardial injury ${ }^{(23)}$. Our results indicated that renal, as well as, extra renal injuries might be impacted by GM therapy in accordance with the study of Zager ${ }^{(33)}$. AKI induces functional alterations in immune cell responsiveness, leukocyte trafficking, and tissue extravasation, both locally in the kidney and in distal organs, such as the heart $^{(34)}$.

Furthermore, the left ventricular sections of GM-treated rats demonstrated loss of cellular architecture, edematous and hemorrhagic features, as well as focal necrosis and infarction, in accordance with previous reports ${ }^{(23)}$. 
Our findings, thus, established a successful rat model for cardio-renal syndrome type 3 where AKI leads to acute cardiac injury ${ }^{(2)}$. Pretreatment of this rat model with the GLP-1 agonist "liraglutide" was associated with improvement of both renal and cardiac biomarkers, as well as, amelioration of the histopathological morphology induced by GM injection in both organs. These results conform to the general trend of the effect of GLP-1R agonists on acute kidney ${ }^{(35)}$ and heart ${ }^{(23,36)}$ injuries previously studied. It deserves to point out that this GLP-1 related effects happened only with the high dose of liraglutide. This means that the beneficial role of liraglutide is dose-dependent, a finding which is in agreement with other researchers ${ }^{(37)}$. In agreement with our results, the GLP-1R agonist significantly attenuated the elevated urea and creatinine and preserved the renal cortex structure in rats subjected to $\mathrm{AKI}^{(38)}$. Furthermore, liraglutide pre-administration improved cardiovascular parameters measured in our study, returning to normal levels as control group.

The incident hypotensive effect of liraglutide in our nephrotoxic rat model is in accordance with the study of Fonseca who found that GLP-1R agonist normalized blood pressure in individuals with higher base line blood pressure values ${ }^{(39)}$. The hypotensive effect of the GLP-1R agonist could be due to its direct action on vascular smooth muscle cells, or mediated through secretion of atrial natriuretic peptide (ANP) (40). The cardiac depression could, also, be improved through direct positive inotropic and chronotropic responses of GLP-1R agonist on the myocardium (41). Mice with genetic deletion of GLP-1R displayed increased LV thickness, impaired LV contractility and diastolic dysfunction ${ }^{(42)}$. Liraglutide reduced infarct size and collagen signals, and attenuated LV dilatation and reduced fractional shortening in the hearts of non-diabetic mice subjected to a brief period of ischaemia-reperfusion ${ }^{(43)}$. In addition, liraglutide normalized cardiac enzymes and histopathological morphology of the cardiac muscle in our rat model, which was in agreement with others ${ }^{(23)}$.

Noticeably, the beneficial action of liraglutide in the present work has been obtained without significant changes in blood glucose level. In agreement with our results Thomson et al. showed improvement of renal hemodynamics by GLP-1R stimulation, independent of its metabolic functions ${ }^{(44)}$. In addition, Hussien et al. demonstrated the renoprotective effect of GLP-1 exenatide in contrast-induced nephropathy, independent of a glucoselowering effect ${ }^{(35)}$. These data suggest that liraglutide may have a direct beneficial effect on both kidney and heart in the rat model used in this study.

Some reports that contradict our results showed that GLP-1R agonist exenatide might produce renal adverse effects during treatment of diabetic patients ${ }^{(45,46)}$. These controversial reports could be attributed to the simultaneous use of other drugs like diuretics and angiotensin II receptor antagonists $^{(19)}$. Moreover, the reported cases by some authors were in a different pathological context ${ }^{(45)}$. In addition, they represent a few cases, thus, representing a small percentage of the total number of patients who used the drug. It's worthy to add that liraglutide is not cleared via renal route and its pharmacokinetics is not altered in states of renal impairment ${ }^{(47)}$. Eventually, no association was found between the degree of renal impairment and the risk of adverse effects of liraglutide ${ }^{(48)}$.

Similarly, Lepore and his coworkers showed no significant effects of the new GLP-1R agonist albiglutide on cardiac function and attributed the modest increase in peak oxygen consumption to non-cardiac effects $^{(49)}$. These controversial results could be related however, to the methodology and 
experimental design used by those investigators.

In the current study we detected signs of oxidative stress in GM- treated animals demonstrated by significant elevation of serum, renal and cardiac lipid peroxide malondialdehyde (MDA), which was considered a common biomarker of in vivo oxidative stress ${ }^{(50)}$. In addition, we showed significant decrease of serum and tissue nonenzymatic (GSH) and enzymatic (catalase and SOD) antioxidants in GM-injected animals, which is in accordance with previous results ${ }^{(28)}$. GM treatment produced oxidative stress in cells of the tubules, both in vivo and in vitro ${ }^{(51,52)}$, and enhanced the release of hydroxyl radicals from $\mathrm{H}_{2} \mathrm{O}_{2}$ and superoxide anions ${ }^{(53)}$. The low levels of the antioxidant defense agents could be attributed to overwhelming production of free radicles, increased lipid peroxidation, and downregulation of associated gene ${ }^{(54)}$. ROS is responsible for cellular injury and necrosis via lipid peroxidation, protein denaturation and DNA damage ${ }^{(29,50)}$.

In spite of the significant elevation of thiobarbituric reactive substances in the cardiac tissue in our study, some reviewers and investigators ignore the role of oxidative stress in cardiac pathology during $\mathrm{AKI}^{(30,55)}$. This could be attributed to the different animal model of AKI studied. We could provide an important role of oxidative stress in cardiac injury of GM induced AKI because GM was considered a potential inducer for oxidative stress in animal studies $^{(8)}$.

Pretreatment of GM-treated animals with liraglutide demonstrated anti-oxidative and anti-inflammatory effects in a dosedependent manner ${ }^{(37,56)}$. GLP-1R agonist in high dose significantly decreased the circulating and the renal and cardiac tissue levels of MDA. It, also, increased the antioxidant parameters. These data are in line with the antioxidative action of GLP-1R agonist in AKI. Hussien et al., previously reported that the GLP-1R against exenatide protects against contrast-induced nephrontoxicity in a rat model of AKI (35). Liraglutide, also, upregulates antioxidant enzymes in endothelial cells subjected to TNF- $\alpha$ induced injury ${ }^{(57)}$. Although the antioxidant effect of GLP-1 is not completely established, a possible explanation could be the cAMP/PKA mediated inhibition of renal NAD $(\mathrm{P}) \mathrm{H}$ oxidase ${ }^{(37)}$.

The significant increase in TNF- $\alpha$, IL$1 \beta$ and IL- 6 in the serum, as well as in renal and cardiac tissue homogenates, of GMtreated animals provided evidence for the role of inflammation in the pathogenesis of cardio-renal syndrome type3. In all cases that developed an inflammatory response, proinflammatory cytokines, are released in both heart and kidney during $\mathrm{AKI}^{(58,59)}$. Furthermore, overexpressed iNOS in renal and cardiac tissue of our rat model might increase the expression of the proinflammatory cytokines, TNF- $\alpha$, IL- $1 \beta$ and IL- ${ }^{(27)}$.

Interestingly, cross talk occurs between oxidative status and inflammation. ROS usually is a signal for increasing proinflammatory cytokines and the latter enhances oxidative status ${ }^{(60,61)}$. Compelling evidence shown that nuclear factor kappa $\mathrm{B}(\mathrm{NF}-\kappa \mathrm{B})$ is activated by oxidative stress ${ }^{(62)}$. NF- $\kappa B$ in turn, modulates the expression of cytokines and iNOS involved in several inflammatory cascades. Thus, a positive feedback circuit is switched off in both the kidney and myocardium of GM-treated animals.

The cytokine profile shown here could explain the impaired myocardial function demonstrated in our study. The proinflammatory cytokines cause impairment of myocyte contractility, abnormal extracellular matrix interaction and accelerated in vitro cardiomyocyte apoptosis, in addition to downregulation of sarcomeric proteins ${ }^{(63)}$. The increased serum and tissue tumor necrosis factor- $\alpha$ (TNF- $\alpha$ ) shown here, specifically produces progressive deterio- 
ration of myocardial contractility and coronary vasoconstriction (64). In animal models, cardiac-specific overexpression of TNF- $\alpha$ is responsible for the development of dilated cardiomyopathy ${ }^{(65)}$. In addition, systemic administration of TNF- $\alpha$ at same plasma concentrations comparable to those found in patients with congestive heart failure (CHF), induced a dilatedcardiomyopathy-like phenotype in animal $\operatorname{models}^{(66)}$.

The significant reduction of the proinflammatory cytokines in the GMnephrotoxic rats pretreated with high dose of liraglutide could provide another mechanism of the potential role of liraglutide in our study. GLP-1 based therapies have been shown to modulate inflammation at multiple sites, including the kidneys and blood vessels $^{(67)}$. Specifically, liraglutide significantly improved the pathological damage of renal podocytes of obese mice on high-fat diet through anti-inflammatory actions. It significantly decreases both TNF- $\alpha$ and NF$\mathrm{kB}$ in the renal tissue ${ }^{(56)}$.

Additionally, liraglutide significantly inhibited the expression of TNF- $\alpha$ in glomerular mesangial cells induced by high glucose $^{(68)}$. Another GLP-1R agonist exendin similarly inhibited production of proinflammatory cytokines in renal tissue in the setting of $\mathrm{AKI}^{(35)}$. It, also, suppressed lipopolysaccharide induced $\mathrm{NF}-\mathrm{\kappa B}$ activetion in macrophages ${ }^{(17)}$. We could, thus, attribute the cardio-renal protective effect of GLP-1 to its antioxidative and antiinflammatory actions, as recently reported $^{(56)}$.

The parallel elevation of NO and iNOS messenger RNA in kidney and cardiac tissues of GM-treated animals is a key finding in the current study. GM increased synthesis of iNOS messenger RNA in renal tissues and cardiac tissue, together with production of NO in serum and tissues. Our results are supported by recent reports ${ }^{(8,9)}$.
ROS are known to enhance the expression of inducible nitric oxide synthase, the rate-limiting enzyme in NO synthesis ${ }^{(69)}$. In vitro studies have shown that GM increases synthesis of iNOS messenger RNA in mesangial cells, together with production of NO ${ }^{(70)}$. The over secreted NO interacts with superoxide to form peroxinitre radicals, $\mathrm{ONOO}^{-}$, which is far more reactive and damaging than its precursors ${ }^{(71)}$. The reactive proximities result in further renal tubular damage in both the kidney ${ }^{(59)}$, and the heart ${ }^{(9)}$. Accordingly, the oxidative status that characterizes our animal model of AKI acts as an inducer to and is potentiated by the high NO level in serum and studied tissues. The accumulation of nitrite radicals was proposed to contribute to heart failure caused by dilated cardiomyopathy ${ }^{(72)}$. Increased expression of iNOS and production of NO has a role in apoptosis of mesangial cells in vitr ${ }^{(73)}$.

On the other hand, liraglutide down regulates iNOS gene expression in both the heart and the kidney, an effect that could alleviate the damaging effect of $\mathrm{NO}$ with returning the NO level in these tissue to comparable values to control animals. The liraglutide effect on iNOS expression in renal tissue agrees with the findings of Chang et al. who showed reduced iNOS protein expression in infected macrophage cell lines (RAW264.7) after stimulation of the GLP-1R with exendin- $4^{(74)}$. The activation of the cAMP/PKA pathway mediated this reduction. Similar effects were debated in animal model of renal I/R injury treated with DPP-4 inhibitors GLP-1R agonists ${ }^{(75,76)}$. Recently, Abdel-Latif and his colleagues demonstrated similar lixisenatiderelated down regulation of iNOS in renal tissues of induced diabetic nephropathy ${ }^{(77)}$. Although down regulation of iNOS in inflamed renal tissue was reported in other studies, the liraglutide lowering effect of NO level and iNOS expression in cardiac tissue of our animal model appears to be a new finding. Similar effects of DPP-4 inhibitors, 
however, were reported in aortic tissues of endotoxemic mice ${ }^{(78)}$ and in the heart of rats with doxorubicin-induced cardiotoxicity ${ }^{(79)}$.

There are contradictory reports of enhancement of NO production in case of acute kidney injuries ${ }^{(35)}$, and in the human umbilical vein endothelial cells ${ }^{(80)}$, under the effect of GLP-1R agonists. This could be attributed to the increased expression of another isoform, which is the eNOS, reported in these studies. The authors did not measure the iNOS isoform and did not give enough explanation to the contradictory effects of the GLP-1 agonists on both proinflammatory cytokines and the NO levels in their study. NO is itself initially a protective agent ${ }^{(81)}$. However, in the setting of inflammation, over expression of the iNOS usually occurs ${ }^{(82)}$, and the deletion of iNOS genes usually protects against cardiac pathologies $^{(83)}$. In our work liraglutide protection against enhanced production of NO could be a direct effect through downregulation of iNOS gene, or indirect through its anti-inflammatory and antioxidant effects discussed before.

In conclusion, the present study established a model of cardio-renal syndrome type 3 where GM-induced AKI produced acute cardiac dysfunction. Moreover, we demonstrated a protective role of GLP-1R agonist (liraglutide), independent of its glucose lowering effect. The improvement was based on antioxidant and anti-inflammatory effects and down regulation of iNOs gene with reduced production of NO.

\section{REFERENCES}

1. Schrier RW. (2007): Cardio-renal versus renocardiac syndrome: is there a difference? Nat Clin Pract Nephrol.;3:637.

2. Ronco C, Bellasi A, Di Lullo L. (2018): Cardio-renal Syndrome: An Overview. Adv Chronic Kidney Dis.; Sep;25(5): 382-390.
3. Selby NM, Kolhe NV, McIntyre CW, Monaghan J, Lawson N, Elliott D, Packington R, Fluck RJ. (2012): Defining the cause of death in hospitalised patients with acute kidney injury. PLoS One.;7(11): e48580.

4. Nikolic T, Petrovic D, Matic S, Turnic TN, Jeremic J, Radonjic K, Srejovic I, Zivkovic $\mathrm{V}$, Bolevich S, Bolevich S, Jakovljevic V. (2020): The influence of folic acid-induced acute kidney injury on cardiac function and redox status in rats. Naunyn Schmiedebergs Arch Pharmacol; Jan;393(1):99-109.

5. Faubel S, Lewis EC, Reznikov L, Ljubanovic D, Hoke TS, Somerset H, Oh DJ, Lu L, Klein CL, Dinarello CA, Edelstein CL. (2007); Cisplatin-induced acute renal failure is associated with an increase in the cytokines interleukin (IL)1beta, IL-18, IL-6, and neutrophil infiltration in the kidney. J Pharmacol Exp Ther.; Jul;322(1): 8-15.

6. Holdsworth SR, Gan PY. (2015); Cytokines: names and numbers you should care about. Clin J Am Soc Nephrol; 10: 2243-54.

7. Giam B, Kaye DM, Rajapakse NW. (2016); Role of renal oxidative stress in the pathogenesis of the cardio-renal syndrome. Heart Lung Circ; 25(8): 874880.

8. Famurewa AC, Maduagwuna EK, Folawiyo AM, Besong EE, Eteudo AN, Famurewa OA, Ejezie FE. (2020); Antioxidant, antiinflammatory, and antiapoptotic effects of virgin coconut oil against antibiotic drug gentamicin-induced nephrotoxicity via the suppression of oxidative stress and modulation of iNOS/NF-kB/caspase-3 signaling pathway in Wistar rats. J Food Biochem; Jan;44(1): e13100.

9. Abo Zakaib F, Ali1 A, Abdellah N, Hafez L O, El-Ghoneimy A A (2020): Sesame Oil Ameliorates Gentamicin-induced Cardiotoxicity in Wistar Albino Rats. Journal of Advanced Veterinary Research Volume 10, Issue 2: 81-87

10. Holst JJ. (2007): The physiology of glucagon-like peptide 1. Physiol Rev.; Oct;87(4): 1409-39. 
11. Zager RA, Johnson AC, Hanson SY. (2003): Radiographic contrast mediainduced tubular injury: evaluation of oxidant stress and plasma membrane integrity. Kidney Int.; Jul;64(1): 128-39.

12. Muskiet MHA, Tonneijck L, Smits MM, van Baar MJB, Kramer MHH, Hoorn EJ, Joles JA, van Raalte DH. (2017): GLP-1 and the kidney: from physiology to pharmacology and outcomes in diabetes. Nat Rev Nephrol. Oct;13(10):605-628.

13. Baggio LL, and Drucker DJ. (2007): Biology of incretins: GLP-1 and GIP. Gastroenterology; 132: 2131-2157.

14. Pyke C, Heller RS, Kirk RK, Ørskov C, Reedtz-Runge S, Kaastrup P, Hvelplund A, Bardram L, Calatayud D, Knudsen LB. GLP-1 receptor localization in monkey and human tissue: novel distribution revealed with extensively validated monoclonal antibody. Endocrinology. 2014 Apr;155(4):1280-90.

15. Noyan-Ashraf MH, Momen MA, Ban K, Sadi AM, Zhou YQ, Riazi AM, Baggio LL, Henkelman RM, Husain M, Drucker DJ. GLP-1R agonist liraglutide activates cytoprotective pathways and improves outcomes after experimental myocardial infarction in mice. Diabetes. 2009 Apr;58(4):975-83.

16. Bose AK, Mocanu MM, Carr RD, Brand CL, Yellon DM. Glucagon-like peptide 1 can directly protect the heart against ischemia/reperfusion injury. Diabetes. 2005 Jan;54(1):146-51.

doi: 10.2337/diabetes.54.1.146.

17. Arakawa M, Mita T, Azuma K, Ebato C, Goto H, Nomiyama T, Fujitani Y, Hirose T, Kawamori R, Watada $\mathrm{H}$. Inhibition of monocyte adhesion to endothelial cells and attenuation of atherosclerotic lesion by a glucagon-like peptide-1 receptor agonist, exendin-4. Diabetes. 2010 Apr;59(4):10307.

18. Kodera R, Shikata K, Kataoka HU, et al. Glucagon-like peptide-1 receptor agonist ameliorates renal injury through its antiinflammatory action without lowering blood glucose level in a rat model of type 1 diabetes. Diabetologia. 2011;54: 965-978.

19. López-Ruiz A, del Peso-Gilsanz C, MeoroAvilés A, Soriano-Palao J, Andreu A, Cabezuelo J, Arias JL. Acute renal failure when exenatide is co-administered with diuretics and angiotensin II blockers. Pharm World Sci. 2010 Oct;32(5):559-61

20. Udupa V, Prakash V. Gentamicin induced acute renal damage and its evaluation using urinary biomarkers in rats. Toxicol Rep. 2018 Nov 30; 6:91-99

21. Moustafa PE, Abdelkader NF, El Awdan SA, El-Shabrawy OA, Zaki HF. Liraglutide ameliorated peripheral neuropathy in diabetic rats: Involvement of oxidative stress, inflammation and extracellular matrix remodeling. J Neurochem. 2018 Jul;146(2):173-185.

22. Milani L, Galindo CM, Turin de Oliveira NM, Corso CR, Adami ER, Stipp MC, Beltrame OC, Acco A. The GLP-1 analog liraglutide attenuates acute liver injury in mice. Ann Hepatol. 2019 NovDec;18(6):918-928.

23. Youssef MI, Mahmoud AA, Abdelghany RH. A new combination of sitagliptin and furosemide protects against remote myocardial injury induced by renal ischemia/reperfusion in rats. Biochem Pharmacol. 2015 Jul 1;96(1):20-9.

24. Bories PN and Bories C. Nitrate determination in biological fluids by an enzymatic one-step assay with nitrate reductase. Clin Chem. 1995 Jun;41(6 Pt 1):904-7.

25. Livak KJ, Schmittgen TD. Analysis of relative gene expression data using real time quantitative PCR and the $2^{\wedge}-\Delta \Delta C T$ method. Methods. 2001;25:402 8.

26. Carleton H.M., Drury R.A.M., Wallington E.A. Carleton's Histological Technique E-Book (5th edition), Oxford University Press, Oxford, New York (1980) 
27. Randjelovic P, Veljkovic S, Stojiljkovic N, Sokolovic D, Ilic I. Gentamicin nephrotoxicity in animals: Current knowledge and future perspectives. EXCLI J. 2017 Mar 24;16:388-399.

28. Cao L, Zhi D, Han J, Kumar Sah S, Xie Y. Combinational effect of curcumin and metformin against gentamicin-induced nephrotoxicity: Involvement of antioxidative, anti-inflammatory and antiapoptotic pathway. J Food Biochem. $2019 \mathrm{Jul}$;43(7):e12836.

29. Parlakpinar H, Tasdemir S, Polat A, BayKarabulut A, Vardi N, Ucar M, Acet A. Protective role of caffeic acid phenethyl ester (cape) on gentamicin-induced acute renal toxicity in rats. Toxicology. $2005 \mathrm{Feb}$ 14;207(2):169-77..

30. Kelly KJ. Distant effects of experimental renal ischemia/reperfusion injury. J Am Soc Nephrol. 2003 Jun;14(6):1549-58.

31. Clementi A, Virzì GM, Brocca A, de Cal M, Pastori S, Clementi M, Granata A, Vescovo G, Ronco C. Advances in the pathogenesis of cardiorenal syndrome type 3. Oxid Med Cell Longev. 2015;2015:148082.

32. Kalogeropoulos AP, Chiladakis JA, Sihlimiris I, Koutsogiannis N, Alexopoulos D. Predischarge QRS score and risk for heart failure after first ST-elevation myocardial infarction. J Card Fail. 2008; 14:225-31.

33. Zager RA. "Subclinical" gentamicin nephrotoxicity: a potential risk factor for exaggerated endotoxin-driven TNF-alpha production. Am J Physiol Renal Physiol. 2007 Jul;293(1):F43-9.

34. Virzì G, Day S, de Cal M, Vescovo G, Ronco C. Heart-kidney crosstalk and role of humoral signaling in critical illness. Crit Care. 2014 Jan 6;18(1):201.

35. Hussien NI, Sorour SM, El-Kerdasy HI, Abdelrahman BA. The glucagon-like peptide-1 receptor agonist Exendin-4, ameliorates contrast-induced nephropathy through suppression of oxidative stress, vascular dysfunction and apoptosis independent of glycaemia. Clin Exp
Pharmacol Physiol. 2018 Aug;45(8):808818.

36. Zheng RH, Bai XJ, Zhang WW, Wang J, Bai F, Yan CP, James EA, Bose HS, Wang NP, Zhao ZQ. Liraglutide attenuates cardiac remodeling and improves heart function after abdominal aortic constriction through blocking angiotensin II type 1 receptor in rats. Drug Des Devel Ther. 2019a Aug 6;13: 2745-2757.

37. Hendarto $\mathrm{H}$, Inoguchi $\mathrm{T}$, Maeda $\mathrm{Y}$ et al. GLP-1 analog liraglutide protects against oxidative stress and albuminuria in streptozotocin-induced diabetic rats via protein kinase A-mediated inhibition of renal $\mathrm{NAD}(\mathrm{P}) \mathrm{H}$ oxidases. Metabolism 2012; 61: 1422-1434.

38. Yang H, Li H, Wang Z, Shi Y, Jiang G, Zeng F. Exendin-4 ameliorates renal ischemia-reperfusion injury in the rat. $\mathrm{J}$ Surg Res. 2013 Dec;185(2):825-32.

39. Fonseca V, Once-Daily Human GLP-1 Analog Liraglutide Reduces Systolic BP \&\#8211; A Meta-Analysis of 6 Clinical Trials. American diabetes Association, Diabetes pro $69^{\text {th }}$ Scientific session; Congress 2009; Abstract 545-P.

40. Kim M, Platt MJ, Shibasaki T, Quaggin SE, Backx PH, Seino S, Simpson JA, Drucker DJ. GLP-1 receptor activation and Epac2 link atrial natriuretic peptide secretion to control of blood pressure. Nat Med. 2013 May;19(5):567-75.

41. Yamamoto $\mathrm{H}$, Lee CE, Marcus JN, Williams TD, Overton JM, Lopez ME, Hollenberg AN, Baggio L, Saper CB, Drucker DJ, Elmquist JK. Glucagon-like peptide-1 receptor stimulation increases blood pressure and heart rate and activates autonomic regulatory neurons. J Clin Invest. $2002 \mathrm{Jul} ; 110(1): 43-52$.

42. Thrainsdottir I, Malmberg K, Olsson A, Gutniak M, Rydén L. Initial experience with GLP-1 treatment on metabolic control and myocardial function in patients with type 2 diabetes mellitus and heart failure. Diab Vasc Dis Res. 2004 May;1(1):40-3.

43. Wang X, Ding Z, Yang F, Dai Y, Chen P, Theus S, Singh S, Budhiraja M, Mehta JL. 
Modulation of myocardial injury and collagen deposition following ischaemiareperfusion by linagliptin and liraglutide, and both together. Clin Sci (Lond). 2016 Aug 1;130(15):1353-62.

44. Thomson SC, Kashkouli A, Singh P. Glucagon-like peptide-1 receptor stimulation increases GFR and suppresses proximal reabsorption in the rat. Am $\mathrm{J}$ Physiol Renal Physiol. 2013 Jan 15;304(2):F137-44.

45. Johansen OE, Whitfield R. Exenatide may aggravate moderate diabetic renal impairment: a case report. $\mathrm{Br} \mathrm{J}$ Clin Pharmacol. 2008 Oct;66(4):568-9.

46. Nandakoban H, Furlong TJ, Flack JR. Acute tubulointerstitial nephritis following treatment with exenatide. Diabet Med. 2013 Jan;30(1):123-5.

47. Brown DX and Evans M. Choosing between GLP-1 Receptor Agonists and DPP-4 Inhibitors: A Pharmacological Perspective. J Nutr Metab. 2012; 2012: 381713.

48. Jacobsen LV, Hindsberger C, Robson R, Zdravkovic M. Effect of renal impairment on the pharmacokinetics of the GLP-1 analogue liraglutide. $\mathrm{Br} \mathrm{J}$ Clin Pharmacol 2009; 68: 898-905

49. Lepore JJ, Olson E, Demopoulos L, Haws T, Fang Z, Barbour AM, Fossler M, DavilaRoman VG, Russell SD, Gropler RJ. Effects of the Novel Long-Acting GLP-1 Agonist, Albiglutide, on Cardiac Function, Cardiac Metabolism, and Exercise Capacity in Patients With Chronic Heart Failure and Reduced Ejection Fraction. JACC Heart Fail. 2016 Jul;4(7):559-566.

50. Lee, J. C., \& Durand, T. (2019). Lipid peroxidation: Analysis and applications in biological systems. Antioxidants, 8, 40-41.

51. Karatas Y, Secilmis MA, Karayaylali I, Doran F, Buyukafsar K, Singirik E, et al. Effect of tempol (4-hydroxy tempo) on gentamicin-induced nephrotoxicity in rats. Fundam Clin Pharmacol. 2004;18: 79 83.
52. Juan $\mathrm{SH}$, Chen $\mathrm{CH}$, Hsu $\mathrm{YH}$, Hou $\mathrm{CC}$, Chen $\mathrm{TH}$, Lin $\mathrm{H}$, et al. Tetramethylpyrazine protects rat renal tubular cell apoptosis induced by gentamicin. Nephrol Dial Transplant. 2007; 22:732-9.

53. Basnakian AG, Kaushal GP, Shah SV. Apoptotic pathways of oxidative damage to renal tubular epithelial cells. Antioxid Redox Signal. 2002; 4:915-924.

54. Yin M, Jiang N, Guo L, Ni Z, Al-Brakati AY, Othman MS, Abdel Moneim AE, Kassab RB. Oleuropein suppresses oxidative, inflammatory, and apoptotic responses following glycerol-induced acute kidney injury in rats. Life Sci. 2019 Sep 1;232: 116634 .

55. White LE, Chaudhary R, Moore LJ, Moore FA, Hassoun HT. Surgical sepsis and organ crosstalk: the role of the kidney. J Surg Res. 2011 May 15;167(2):306-15.

56. Ye Y, Zhong X, Li N, Pan T. Protective effects of liraglutide on glomerular podocytes in obese mice by inhibiting the inflammatory factor TNF- $\alpha$-mediated NF$\kappa \mathrm{B}$ and MAPK pathway. Obes Res Clin Pract. 2019 Jul-Aug;13(4):385-390.

57. Shiraki A, Oyama J, Komoda H, Asaka M, Komatsu A, Sakuma M, Kodama K, Sakamoto Y, Kotooka N, Hirase T, Node K. The glucagon-like peptide 1 analog liraglutide reduces TNF- $\alpha$-induced oxidative stress and inflammation in endothelial cells. Atherosclerosis 2012; 221: $375-382$

58. Chopra M, Golden HB, Mullapudi S, Dowhan W, Dostal DE, Sharma AC. Modulation of myocardial mitochondrial mechanisms during severe polymicrobial sepsis in the rat. PLoS One. 2011;6(6): e21285.

59. Liu Y, Fu X, Gou L, Li S, Lan N, Zheng Y, Yin $X$. L-citrulline protects against glycerol-induced acute renal failure in rats. Ren Fail. 2013;35(3):367-73.

60. Kuhad A, Chopra K. Attenuation of diabetic nephropathy by tocotrienol: involvement of NFkB signaling pathway. Life Sci. 2009 Feb 27;84(9-10):296-301. 
61. Zhou Z, Wang L, Song Z, Lambert JC, McClain CJ, Kang YJ. A critical involvement of oxidative stress in acute alcohol-induced hepatic TNF-alpha production. Am J Pathol. 2003 Sep; 163(3): 1137-46.

62. Zheng H, Gao J, Man S, Zhang J, Jin Z, Gao W. The protective effects of Aquilariae Lignum Resinatum extract on 5Fuorouracil-induced intestinal mucositis in mice. Phytomedicine. 2019b Feb 15; 54: 308-317.

63. Patten M, Krämer E, Bünemann J, Wenck $\mathrm{C}$, Thoenes $\mathrm{M}$, Wieland $\mathrm{T}$, Long $\mathrm{C}$. Endotoxin and cytokines alter contractile protein expression in cardiac myocytes in vivo. Pflugers Arch. 2001 Sep; 442 (6):9207.

64. Prabhu SD. Cytokine-induced modulation of cardiac function. Circ Res. 2004;95(December (12)):1140-1153

65. Kubota T., Tiernan C.F., Frye C.S., Slawson S.E., Lemster B.H., Koretsky A.P., Demetris A.J., Feldman A.M. Dilated cardiomyopathy in transgenic mice with cardiac-specific overexpression of tumor necrosis factor-alpha. Circ. Res. 1997;81: 627-635.

66. Bozkurt B, Kribbs SB, Clubb FJ Jr, Michael LH, Didenko VV, Hornsby PJ, Seta Y, Oral $\mathrm{H}$, Spinale FG, Mann DL. Pathophysiologically relevant concentrate-ions of tumor necrosis factor-alpha promote progressive left ventricular dysfunction and remodeling in rats. Circulation. $1998 \mathrm{Apr}$ 14; 97(14):1382-91.

67. Lee, Y.S. and Jun, H.S. Anti-inflammatory effects of GLP-1-based therapies beyond glucose control. Mediators Inflamm. 2016, 3094642 .

68. Dai Y, Mehta JL, Chen M. Glucagon-like peptide-1 receptor agonist liraglutide inhibits endothelin-1 in endothelial cell by repressing nuclear factor-kappa B activation. Cardiovasc Drugs Ther. 2013 Oct;27(5):371-80.

69. Sanchez-Gonzalez, P. D., LopezHernandez, F. J., Perez-Barriocanal, F., Morales, A. I., \& Lopez-Novoa, J. M.
(2011). Quercetin reduces cisplatin nephrotoxicity in rats without compromising its anti-tumour activity. Dialysis and Transplantation, 26, 34843495.

70. Rivas-Cabanero L, Rodriguez-Lopez AM, Martinez-Salgado C, Saura M, Lamas S, López-Novoa JM. Gentamicin treatment increases mesangial cell nitric oxide production. Exp Nephrol. 1997;5: 2330.

71. Beckman JS, Beckman TW, Chen J, Marshall PA, Freeman BA. Apparent hydroxyl radical production by peroxynitrite: implications for endothelial injury from nitric oxide and superoxide. Proc Natl Acad Sci U S A. 1990 Feb; 87(4): $1620-4$

72. Vejlstrup NG, Bouloumie A, Boesgaard S, Andersen CB, Nielsen-Kudsk JE, Mortensen SA, Kent JD, Harrison DG, Busse R, Aldershvile J. Inducible nitric oxide synthase (iNOS) in the human heart: expression and localization in congestive heart failure. J Mol Cell Cardiol. 1998 Jun; 30(6):1215-23.

73. Martinez-Salgado C, Eleno N, Morales AI, Pérez-Barriocanal F, Arévalo M, López Novoa JM. Gentamicin treatment induces simultaneous mesangial proliferation and apoptosis in rats. Kidney Int. 2004; 65: 2161-71.

74. Chang SY, Kim DB, Ryu GR, Ko SH, Jeong IK, Ahn YB et al. (2013). Exendin-4 inhibits iNOS expression at the protein level in LPSstimulated Raw264.7 macrophage by the activation of cAMP/PKA pathway. J Cell Biochem 114: 844-853

75. Vaghasiya J, Sheth N, Bhalodia Y, Manek R. Sitagliptin protects renal ischemia reperfusion induced renal damage in diabetes. Regul Pept. 2011 Jan 17;166(13):48-54.

76. Vaghasiya JD, Sheth NR, Bhalodia YS, Jivani NP. Exaggerated liver injury induced by renal ischemia reperfusion in diabetes: effect of exenatide. Saudi J Gastroenterol. 2010 Jul-Sep; 16(3):174-80. doi: 10. 
4103/1319-3767.65187. PMID: 20616412; PMCID: PMC3003206.

77. Abdel-Latif RG, Ahmed AF, Heeba GH. Low-dose lixisenatide protects against early-onset nephropathy induced in diabetic rats. Life Sci. 2020 Dec 15;263:118592.

78. Steven S, Jurk K, Kopp M, Kröller-Schön S, Mikhed Y, Schwierczek K, Roohani S, Kashani F, Oelze M, Klein T, Tokalov S, Danckwardt S, Strand S, Wenzel P, Münzel $\mathrm{T}$, Daiber A. Glucagon-like peptide-1 receptor signalling reduces microvascular thrombosis, nitro-oxidative stress and platelet activation in endotoxaemic mice. $\mathrm{Br}$ J Pharmacol. 2017 Jun;174(12):1620-1632.

79. Kelleni MT, Amin EF, Abdelrahman AM. Effect of Metformin and Sitagliptin on Doxorubicin-Induced Cardiotoxicity in Rats: Impact of Oxidative Stress, Inflammation, and Apoptosis. J Toxicol. 2015; 2015:424813.

80. Hattori Y, Jojima T, Tomizawa A, Satoh H, Hattori S, Kasai K, Hayashi T. A glucagon- like peptide-1 (GLP-1) analogue, liraglutide, upregulates nitric oxide production and exerts anti-inflammatory action in endothelial cells. Diabetologia. 2010 Oct;53(10):2256-63.

81. Wink DA, Hanbauer I, Krishna MC, DeGraff W, Gamson J, Mitchell JB. Nitric oxide protects against cellular damage and cytotoxicity from reactive oxygen species. Proc Natl Acad Sci USA 1993;90: 9813-7.

82. Csont T, Viappiani S, Sawicka J, Slee S, Altarejos JY, Batinić-Haberle I, Schulz R. The involvement of superoxide and iNOSderived NO in cardiac dysfunction induced by pro-inflammatory cytokines. J Mol Cell Cardiol. 2005 Nov;39(5): 833-40.

83. Ullrich R, Scherrer-Crosbie M, Bloch KD, Ichinose F, Nakajima H, Picard MH, et al. Congenital deficiency of nitric oxide synthase 2 protects against endotoxininduced myocardial dysfunction in mice. Circulation 2000;102: 1440-6 


\section{Atef M. Abood, et al.,}

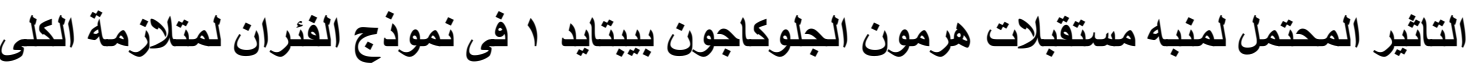

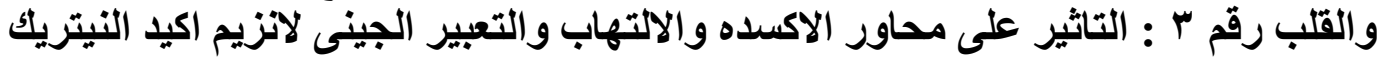

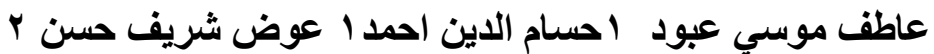

كلية الطب ـ قسم الفسيولجى جامعة عين شمس وجامعة الملاك عبدالعزيز ا كلية الطب قسم التشريح جامعة الازهر وجامعة

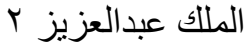

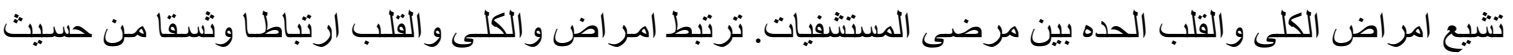

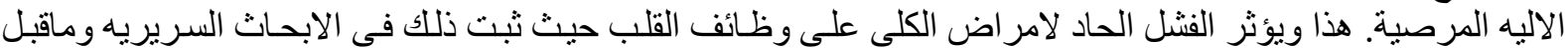
السريريه و هو مايسمى بمتلاومة الكلى و القلب النوع النو الثنالث.

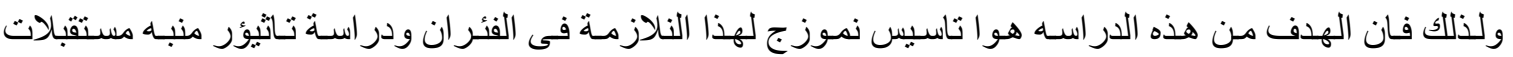
هرمون الجلوكاجون بييتايد الف على هذه الانه المتلازمة.

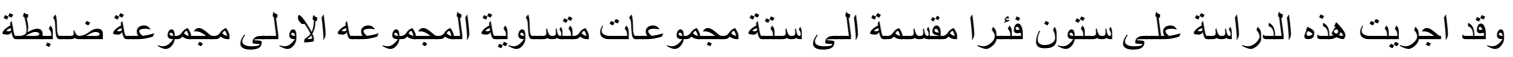

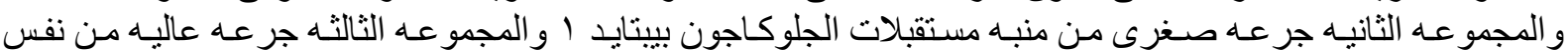

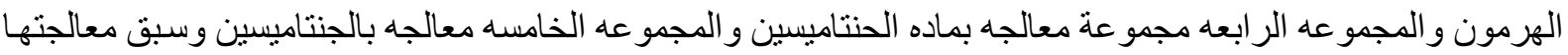

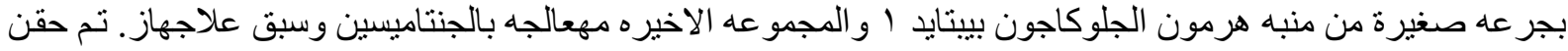

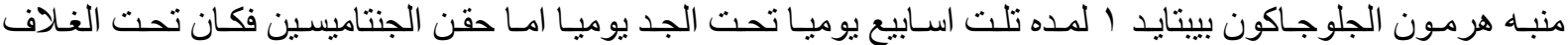
البريتونى بدا من اليوم الخامس عشر الى اليوم الواحد والعشرين.

وقد اظهرت النتائج حجوث تغيير ات فى اتسجة القلب و الكلى بالاضافة الى ارتفاع فى نسبة اليوريا و الكرياتينمين فى في الكي

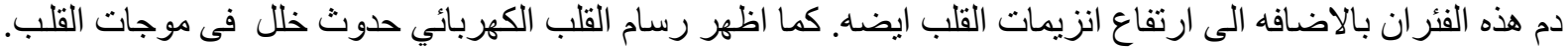

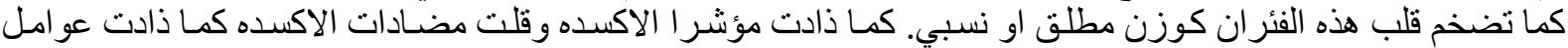

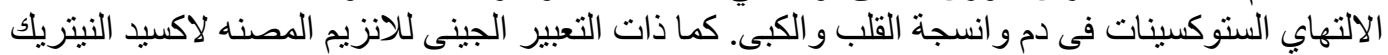

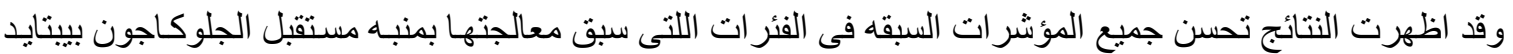
ا وكن فى الجر عه العاليه فقط. كما ساعد هذا الدو اء فى خفض الته التعبير الجينى لانزيم المصنع لاكسيد النيتريك.

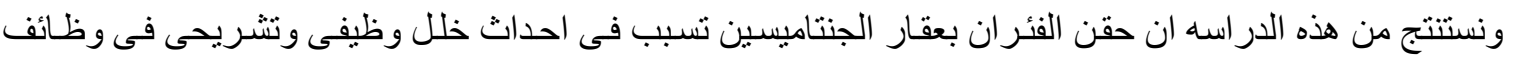

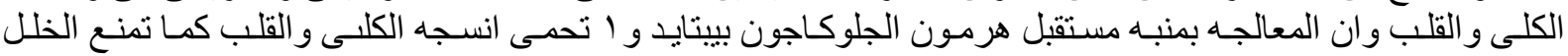
الوظيفى لهما من خلال العمل كمضاد للاكسده وللالتهاب وتقليل التعبير الجينى لانزيم اكسيد النيتريك 